\title{
PELUANG MENGEMBANGKAN KEWIRAUSAHAAN DESA BERBASIS POTENSI DESA
}

\author{
(Studi deskriptif di Desa Karang Rejo Kecamatan Negeri Katon Kabupaten Pesawaran, \\ Kampung Suka Jawa Kecamatan Bumi Ratu Kabupaten Lampung Tengah dan Desa \\ Sidoasri Kecamatan Candi Puro Kabupaten Lampung Selatan Propinsi Lampung)
}

\author{
EXPANDING OPPORTUNITIES BASED RURAL ENTREPRENEURSHIP \\ POTENTIAL OF THE VILLAGE \\ (Descriptive Study In District Of Foreign Karang Rejo Katon Pesawaran District, \\ Kampong Java Subdistrict Earth Love Queen Central Lampung Regency And Village \\ Temple Puro Sidoasri District Of South Lampung Lampung Province)
}

\author{
Ray Septianis Kartika \\ Badan Penelitian dan Pengembangan Kementerian Dalam Negeri \\ Jalan Kramat Raya No. 132, Senen - Jakarta Pusat \\ E-mail: raseka_twpa@yahoo.com
}

Diterima: 11 Oktober 2013; direvisi: 31 Oktober 2013; disetujui: 10 November 2013

\begin{abstract}
Abstrak
Penelitian ini bertujuan untuk menganalisa peluang kewirausahaan desa berbasis potensi desa. Dengan menggunakan metode deskriptif analitis, penggalian informasi diperoleh dari pelaku usaha berjumlah 3 orang dan pejabat Pemerintah Daerah. Hasil penelitian mengungkapkan peluang pengembangan kewirausahaan desa sangat besar dan dikategorikan sebagai usaha kecil. Produk unggulannya yaitu bidang pertanian, perkebunan dan adanya pemanfaatan sumber daya alam yang juga potensial. Kewirausahaan yang ada di desa memiliki prospek yang baik asalkan didukung oleh sarana prasarana, regulasi yang pro ke pelaku usaha dan adanya kepercayaan dari pihak lain untuk menjaring kemitraan kepada pelaku usaha.

Kata kunci: Peluang, Pengembangan, Kewirausahaan, Potensi, Desa.
\end{abstract}

\begin{abstract}
This study aims to analyze the potential entrepreneurial opportunities based rural village. By using the method of descriptive analysis, extracting information obtained from businesses totaling 3 people and local government officials. The results reveal entrepreneurial rural development opportunities are very large and are categorized as small businesses. Superior products namely agriculture, plantations and the use of natural resources are also potential. Entrepreneurship in the village has good prospects as long as supported by infrastructure, regulatory pro to the business and the trust of the other party to solicit partnerships to businesses

Keywords: Opportunity, Development, Entrepreneurship, Potential, Village.
\end{abstract}

\section{PENDAHULUAN}

Kewirausahaan desa saat ini telah menjadi prospek bisnis yang menjanjikan. Keberadaan para pelaku usaha yang tidak ada matinya, seakan menunjukkan bahwa usaha desa patut dikedepankan dan dikembangkan serta menjadi perhatian bagi semua pihak. Berbagai potensi dan berlimpahnya sumber daya alam yang tersedia menjadikan dukungan tersendiri buat pelaku usaha untuk memperoleh bahan baku sesuai dengan bidang usaha yang ditekuninya. Pengembangan kewirausahaan desa yang sedang digalakkan ini selaras dengan Visi 2025, yang diwujudkan melalui 3 (tiga) hal yaitu: (1) Peningkatan nilai tambah dan perluasan rantai nilai proses produksi serta distribusi dari pengelolaan aset dan akses (potensi) SDA, geografis wilayah, dan
SDM, melalui penciptaan kegiatan ekonomi yang terintegrasi dan sinergis di dalam maupun antarkawasan pusat-pusat pertumbuhan ekonomi, (2) Mendorong terwujudnya peningkatan efisiensi produksi dan pemasaran serta integrasi pasar domestik dalam rangka penguatan daya saing dan daya tahan perekonomian nasional, (3) Mendorong penguatan sistem inovasi nasional di sisi produksi, proses, maupun pemasaran untuk penguatan daya saing global yang berkelanjutan, menuju innovationdriven economy.

Dijelaskan pula oleh Cakera (2012) bahwa untuk membangun perekonomian Indonesia harus digalakkan pembangunan masyarakat berwirausaha. Hasan (2011) juga mengutarakan bahwa di Indonesia masih minim jumlah wirausaha. Oleh karenanya pembangunan masyarakat wirausaha harus dilakukan 
di desa-desa di Indonesia, dan idealnya untuk membangun wirausaha di desa harus disediakan dana Rp. 5 miliar per desa setiap tahun. Saat ini, dana yang tersedia masih minim, karena Kemenakertrans hanya mempunyai anggaran Rp. 350 miliar tahun 2012 untuk mendidik masyarakat jadi wirausaha.

Senada dengan data di atas, Radjasa (2012) juga mengatakan bahwa Indonesia memerlukan sedikit-dikitnya 4 juta wirausaha untuk mendukung sektor perekonomian bangsa agar lebih tangguh di masa depan. Jumlah wirausaha yang ada saat ini masih sekitar $1,56 \%$ dari jumlah penduduk, padahal idealnya minimal $2 \%$ atau sekitar 4 jutaan wirausaha. Lebih lanjut Radjasa menyatakan bahwa pemerintah Indonesia menargetkan pada 2025 Indonesia bisa masuk jajaran 10 besar dunia sebagai negara dengan kekuatan ekonomi tangguh, dengan cara pemerintah terus mendorong kalangan pemuda yang tinggal di desa maupun kota untuk tidak menganggur, tapi melakukan sesuatu yang berguna dan bermanfaat dengan membuka usaha, semisal bengkel, usaha makanan atau agrobisnis. Dalam hal penciptaan wirausaha baru, pemerintah telah menyiapkan berbagai dukungan, seperti pendidikan, pelatihan atau pendampingan, kemudahan akses permodalan, dan bantuan untuk berkolaborasi dengan sektor usaha besar.

Seperti halnya di Provinsi Lampung, jumlah wirausaha di Lampung sebanyak $27 \%$ dari jumlah penduduk yang ada sebesar 5.436 juta jiwa. Jumlah wirausaha yang ada tersebut, dengan berpegangan pada potensi desa yang ada, seperti SDA tersedia sangat prospektif dan dapat diandalkan seperti pertanian, perikanan, peternakan, pertambangan, pariwisata, kehutanan sampai perkebunan dengan hasil produksi kopi mencapai 143.050 ton, produksi kakao 22.976 ton, lalu diikuti produksi kelapa dalam lebih dari 112.631 ton, lada 24.011 ton, karet 54.461 ton, kelapa sawit 367.840 ton, dan tebu 693.613 ton. Dari hasil produksi tebu itu Lampung memberi kontribusi 35\% dari total produksi gula nasional, meningkat dibanding kontribusi 2005 yang mencapai $20 \%$.

Terkait dengan potensi desa yang dimiliki Provinsi Lampung, maka wirausaha di wilayah tersebut masih perlu ditingkatkan, khususnya wirausaha di perdesaan. Hal ini dikarenakan wirausaha adalah salah satu jalan untuk menuju kesuksesan hidup, dan untuk itu perlu dukungan pemerintah daerah dan perbankan (Lampung Post.Com., 2011). Jangan sampai Indonesia makmur dengan sumber daya alam yang potensial, namun untuk memperoleh bahan baku produksi usaha harus menunggu ekspor dari negara lain. Dengan demikian prospek positif wirausaha yang ada di Propinsi Lampung dapat menjadi mata rantai yang dapat menggerakkan perekonomian sekaligus menjaga kelestarian potensi desa yang ada di wilayah Lampung. Dengan melihat kekayaan SDA yang ada di Provinsi Lampung dan jumlah wirausaha yang tersedia, sangatlah memungkinkan perkembangannya akan melaju dengan pesat tanpa mengurangi nilai-nilai kearifan lokal yang ada. Melalui penelitian ini akan di bahas secara tuntas perihal prospek perkembangan kewirausahaan desa berbasis potensi desa di Provinsi Lampung, dengan perumusan masalah yang akan diangkat dalam penelitian ini adalah bagaimana peluang wirausaha di Provinsi Lampung, dengan bertujuan untuk menganalisa peluang kewirausahaan desa di Provinsi Lampung.

Sampai saat ini konsep kewirausahaan masih terus berkembang. Pusat Kurikulum Balitbang Kemendiknas (2012) menyatakan kewirausahaan adalah suatu sikap, jiwa, dan kemampuan untuk menciptakan sesuatu yang baru yang sangat bernilai dan berguna bagi dirinya dan orang lain. Kewirausahaan merupakan sikap mental dan jiwa yang selalu aktif atau kreatif berdaya, bercipta, berkarya dan bersahaja dan berusaha dalam rangka meningkatkan pendapatan dalam kegiatan usahanya Scarborough dan Thomas Zimmerer (2003) menyatakan bahwa "An entrepreneur is one who creates a new business in the face of risk and uncertainty for the purpose of achieving profit and growth by identifying opportunities and asembling the necessary resources to capitalze on those opportunities." Wirausahawan adalah orang-orang yang memiliki kemampuan melihat dan menilai kesempatan-kesempatan bisnis; mengumpulkan sumberdaya-sumberdaya yang dibutuhkan untuk mengambil tindakan yang tepat, mengambil keuntungan serta memiliki sifat, watak dan kemauan untuk mewujudkan gagasan inovatif kedalam dunia nyata secara kreatif dalam rangka meraih sukses/ meningkatkan pendapatan. Wirausahawan adalah kaum yang menciptakan peluang, bukan hanya menunggu peluang yang diciptakan orang lain, dan bahkan bisa memberikan peluang kepada orang lain. Jadi intinya, seorang wirausaha adalah orang-orang yang memiliki karakter wirausaha dan mengaplikasikan hakikat kewirausahaan dalam hidupnya. Dengan kata lain, wirausaha adalah orangorang yang memiliki jiwa kreativitas dan inovatif yang tinggi dalam hidupnya. Prawirokusumo (2007) wirausaha adalah mereka yang melakukan upayaupaya kreatif dan inovatif dengan jalan mengembangkan ide, dan meramu sumberdaya untuk menemukan peluang (opportunity) dan perbaikan (preparation) hidup).

Suryana (2001), kewirausahaan (enterpreneurship) muncul apabila seseorang individu berani mengembangkan usaha-usaha dan ide-ide barunya. Proses kewirausahaan meliputi semua fungsi, aktivitas dan tindakan yang berhubungan dengan perolehan peluang dan penciptaan organisasi usaha Esensi dari kewirausahaan adalah menciptakan nilai tambah di pasar melalui proses pengkombinasian sumberdaya dengan cara-cara baru dan berbeda agar dapat bersaing. Zimmerer (2006), nilai tambah tersebut dapat diciptakan melalui cara- 
cara sebagai berikut: (1) Pengembangan teknologi baru (developing new technology), (2) Penemuan pengetahuan baru (discovering new knowledge), (3) Perbaikan produk (barang dan jasa) yang sudah ada (improving existing products or services), dan (4) Penemuan cara-cara yang berbeda untuk menghasilkan barang dan jasa yang lebih banyak dengan sumber daya yang lebih sedikit (finding different ways of providing more goods and services with fewer resources).

Pengembangan kewirausahaan dilaksanakan sesuai dengan minat, bakat, potensi kaum muda, potensi daerah, dan arah pembangunan nasiona. Fasilitasi pengembangan kewirausahaan dilaksanakan melalui: (1) pelatihan dengan penyediaan instruktur dan tenaga pendamping, pengembangan kurikulum, pendirian inkubator kewirausahaan, penyediaan prasarana dan sarana maupun penyediaan pendanaan; (2) pemagangan; (3) pembimbingan; (4) pendampingan; (5) kemitraan melalui pengembangan sumberdaya manusia, pemberian bantuan manajemen, pengalihan teknologi dan dukungan teknis, perluasan akses pasar, pengembangan jaringan kemitraan pemuda lokal, nasional, regional, maupun internasional, penyediaan akses informasi, akses peluang usaha, dan penguatan permodalan; (6) promosi melalui penyelenggaraan pameran wirausaha muda, baik lokal, nasional, regional, maupun internasional, pengenalan produk atau promosi penggunaan barang dan jasa, sosialisasi gagasan atau penemuanpenemuan baru serta kemudahan pengurusan hak kekayaan intelektual, pengembangan jaringan promosi bersama melalui media cetak, elektronik, dan media luar ruang, gelar karya atau demonstrasi produk; dan (7) bantuan akses permodalan dengan membentuk lembaga permodalan kewirausahaan.

Selain kewirausahaan, juga perlu memberikan pelatihan kepemimpinan dan organisasi supaya para pemuda mampu mengembangkan program yang dirintis secara berkelanjutan di perdesaan. Jadi, pengembangan kewirausahaan desa haruslah disesuaikan atau dikaitkan dengan kondisi riil potensi desa itu sendiri. Menurut Muhi (2011), potensi desa mencakup: (1) potensi geografis desa (aspek topologi dan aspek non biotik); (2) potensi sumberdaya alam di wilayah desa (sumberdaya tanah, sumberdaya hutan, serta sumberdaya air dan kelautan); (3) potensi sumberdaya manusia di perdesaan (angkatan kerja dan pengangguran); (4) sumberdaya ekonomi di perdesaan (potensi ekonomi desa, peluang kerja, dan usaha di desa); (5) potensi sosial dan budaya di perdesaan; (6) potensi kelembagaan di desa; (7) sarana dan prasarana di desa. Sedangkan menurut BPS (2003), potensi desa meliputi: keterangan umum desa, kependudukan, ketenagakerjaan, perumahan dan lingkungan hidup, fasilitas pendidikan, fasilitas kesehatan, gizi dan keluarga berencana, sosial budaya, rekreasi, hiburan, kesenian dan olah raga, angkutan, komunikasi dan informasi, keuangan desa, politik dan keamanan, otonomi desa dan program pengentasan kemiskinan, serta keterangan aparat desa. Berdasarkan Permendagri No. 12 Tahun 2007 Tentang Pedoman Penyusunan dan Pendayagunaan Data Profil Desa dan Kelurahan pasal 1 ayat 8, dijelaskan potensi Desa dan Kelurahan adalah keseluruhan sumber daya yang dimiliki atau digunakan oleh desa dan kelurahan baik sumber daya manusia, sumber daya alam dan kelembagaan maupun prasarana dan sarana untuk mendukung percepatan kesejahteraan masyarakat.

Dengan demikian tujuan pengembangan kewirausahaan desa hanya akan tercapai secara optimal apabila tokoh desa, dalam hal ini kepala desa, memiliki spirit atau semangat kewirausahaan desa yang tinggi (Anto, 2011). Membangun dan membangkitkan semangat kewirausahaan di desa, harus ada support dan motivasi yang tidak kenal lelah untuk merubah cara berpikir masyarakat. Masyarakat yang semula memiliki mental pekerja seyogyanya di arahkan memiliki semangat dan keberanian untuk berwirausaha.

\section{METODE PENELITIAN}

Penelitian ini menggunakan metode deskriptif analitis dengan studi perkembangan untuk mengetahui tumbuh kembangnya kewirausahaan desa. Penelitian deskriptif berusaha mendeskripsikan dan menginterpretasikan sesuatu dalam hal ini proses tentang kewirausahaan desa, pendapat yang berkembang tentang kewirausahaan desa maupun akibat yang terjadi ketika usaha di desa berlangsung. Locus penelitian di fokuskan pada Desa Karang Rejo Kecamatan Negeri Katon Kabupaten Pesawaran, Kampung Suka Jawa Kecamatan Bumi Ratu Kabupaten Lampung Tengah dan Desa Sidoasri Kecamatan Candi Puro Kabupaten Lampung Selatan Propinsi Lampung, pertimbangannya adalah dengan melihat Pendapatan Domestik Regional Bruto yang diperoleh Kabupaten Lampung Tengah sebesar 16,650,401, Kabupaten Lampung Selatan sebanyak 11,255,337 dan Kabupaten Pesawaran sebesar $6,047,546$. Penggalian informasi diperoleh dari para pelaku usaha berjumlah 3 orang pada masing-masing sampel dan Pejabat Pemerintah Daerah selaku regulator berjumlah 1 orang, dengan menggunakan purposive sampling. Analisa datanya dengan menggunakan data kualitatif, yang diinterpretasikan ke dalam ranah pemikiran penulis dan mengaitkan hasil temuan dilapangan dengan teori baku yang sudah ada. 
HASIL DAN PEMBAHASAN

\section{Kondisi Wilayah Kabupaten}

Pada Kabupaten Pesawaran, jumlah pencari kerja yang terdaftar Tahun 2011 adalah 420 LakiLaki dan 381 perempuan. Banyaknya perusahaan tenaga kerja menurut klasifikasi Baku lapangan Usaha Indonesia (KBLI) dan jenis kelamin di Kabupaten Pesawaran 2011, dapat diidentifikasi yaitu:
Pada sektor pertanian di kabupaten pesawaran memiliki luas panen dan produksi padi adalah 36.014 Ha dan 185.416 Ton. Sedangkan tanaman pangan lainnya masing-masing yaitu Jagung $11.518 \mathrm{Ha}$ dan 81,673 Kedelai $250 \mathrm{Ha}$ dan 270 Ton, kacang tanah 313 Ha dan 651 Ton, Kacang Hijau 59 Ha dan 42 Ton, Ubi Kayu 3.670 Ha dan 75.482 Ton, ubi jalar $170 \mathrm{Ha}$ dan 1.509 Ton. Produksi tanaman hortikultura terbesar pada komoditi sayuran adalah jahe yaitu 31,486 Ton dan luas panen terbanyak

Tabel 1. Klasifikasi Baku Lapangan Usaha Indonesia di Kabupaten Pesawaran.

\begin{tabular}{|c|c|c|c|c|c|}
\hline \multirow[t]{2}{*}{ No } & \multirow[t]{2}{*}{ Lapangan Usaha } & \multirow{2}{*}{$\begin{array}{c}\text { Jumlah } \\
\text { perusahaan }\end{array}$} & \multicolumn{2}{|c|}{$\begin{array}{l}\text { Jumlah tenaga } \\
\text { kerja/buruh }\end{array}$} & \multirow{2}{*}{$\begin{array}{c}\text { Jumlah } \\
\text { Total }\end{array}$} \\
\hline & & & Laki-laki & Perempuan & \\
\hline 1. & $\begin{array}{l}\text { Pertanian, kehutanan } \\
\text { dan perikanan }\end{array}$ & 104 & 2.481 & 1.125 & 3.606 \\
\hline 2. & $\begin{array}{l}\text { Pertambangan dan } \\
\text { Penggalian }\end{array}$ & 3 & 221 & 9 & 230 \\
\hline 3. & $\begin{array}{l}\text { Penggadaan Listrik, } \\
\text { Gas, Uap/Air Panas } \\
\text { dan Udara Dingin }\end{array}$ & 2 & 63 & 27 & 90 \\
\hline 4. & $\begin{array}{l}\text { Reparasi dan } \\
\text { Perawatan Mobil dan } \\
\text { sepeda motor }\end{array}$ & 19 & 93 & 29 & 122 \\
\hline 5. & $\begin{array}{l}\text { Informasi dan } \\
\text { Komunikasi }\end{array}$ & 1 & 6 & 1 & $\begin{array}{l}7 \\
6 .\end{array}$ \\
\hline 6. & $\begin{array}{l}\text { Jasa Keuangan dan } \\
\text { Asuransi }\end{array}$ & 2 & 12 & 6 & 18 \\
\hline 7. & $\begin{array}{l}\text { Jasa Pendidikan } \\
\text { Total }\end{array}$ & 1 & 5 & 1 & $\begin{array}{c}6 \\
4.079 \\
\end{array}$ \\
\hline
\end{tabular}

Sumber Data: Dinas sosial Tenaga Kerja dan Transmigrasi Kab. Pesawaran

Tabel 2. Identifikasi dan Inventarisasi Usaha Ekonomi Keluarga.

\begin{tabular}{|c|c|c|c|c|c|c|c|c|c|}
\hline No & Desa & \multicolumn{5}{|c|}{ Jumlah Pelaku Usaha } & \multicolumn{2}{|c|}{ Jenis Usaha } & Permasalahan \\
\hline 1. & $\begin{array}{l}\text { Sinar } \\
\text { Bandung }\end{array}$ & 11 & 33 & 5 & 92 & 3 & $\begin{array}{l}\text { Pengelolaan } \\
\text { Lahan } \\
\text { Pertanian } \\
\text { dan } \\
\text { Perkebunan }\end{array}$ & $\begin{array}{l}\text { Padi sawit } \\
\text { dan coklat }\end{array}$ & $\begin{array}{l}\text { Modal Peralatan, } \\
\text { Manajemen }\end{array}$ \\
\hline 3. & Bangunsari & 31 & 45 & 5 & 62 & 24 & $\begin{array}{l}\text { Pengelolaan } \\
\text { lahan } \\
\text { pertanian } \\
\text { dan } \\
\text { perkebunan }\end{array}$ & $\begin{array}{l}\text { Jagung, } \\
\text { kakao dan } \\
\text { singkong }\end{array}$ & $\begin{array}{l}\text { Manajemen dan } \\
\text { SDA }\end{array}$ \\
\hline 5. & Lumbirejo & 36 & 201 & 33 & 87 & 16 & $\begin{array}{l}\text { Pengolhan } \\
\text { lahan } \\
\text { pertanian } \\
\text { dan } \\
\text { perkebunan }\end{array}$ & $\begin{array}{l}\text { Jagung, } \\
\text { Kelapa } \\
\text { dalam } \\
\text { Pisang, padi } \\
\text { dan gula } \\
\text { merah }\end{array}$ & $\begin{array}{l}\text { Modal, peralatan } \\
\text { dan manajemen }\end{array}$ \\
\hline 6. & Sidomulyo & 32 & 63 & 35 & 116 & 6 & $\begin{array}{l}\text { Pengolahan } \\
\text { lahan } \\
\text { pertanian }\end{array}$ & $\begin{array}{l}\text { Padi dan } \\
\text { Singkong }\end{array}$ & $\begin{array}{l}\text { Modal, } \\
\text { Manajemen dan } \\
\text { Pemasaran }\end{array}$ \\
\hline
\end{tabular}




\begin{tabular}{|c|c|c|c|c|c|c|c|c|c|}
\hline 7. & Trisno maju & 38 & 94 & 120 & 198 & 5 & $\begin{array}{l}\text { Pengolahan } \\
\text { lahan } \\
\text { pertanian } \\
\text { dan } \\
\text { perkebunan }\end{array}$ & $\begin{array}{l}\text { Gula merah, } \\
\text { sayur- } \\
\text { syauran } \\
\text { Jagung Padi } \\
\text { dan } \\
\text { Singkong }\end{array}$ & Modal dan SDA \\
\hline 8. & Roworejo & 38 & 79 & 44 & 112 & 15 & $\begin{array}{l}\text { Pengolahan } \\
\text { lahan } \\
\text { pertanian, } \\
\text { perkebunan } \\
\text { dan industri } \\
\text { kecil }\end{array}$ & $\begin{array}{l}\text { Jagung, } \\
\text { sawit, coklat, } \\
\text { tahu dan } \\
\text { geblek }\end{array}$ & $\begin{array}{l}\text { Modal, } \\
\text { peralatan, } \\
\text { transportasi dan } \\
\text { pemasaran }\end{array}$ \\
\hline 9. & Pujo Rahayu & 38 & 24 & 101 & 95 & 10 & $\begin{array}{l}\text { Pengolahan } \\
\text { lahan } \\
\text { pertanian } \\
\text { dan industri } \\
\text { kecil }\end{array}$ & $\begin{array}{l}\text { Jagung, } \\
\text { sawit, coklat, } \\
\text { tahu dan } \\
\text { geblek }\end{array}$ & $\begin{array}{l}\text { Modal, } \\
\text { peralatan, } \\
\text { transportasi dan } \\
\text { pemasaran }\end{array}$ \\
\hline 10. & Kacang Rejo & 18 & 35 & 88 & 80 & 2 & $\begin{array}{l}\text { Pengolahan } \\
\text { singkong } \\
\text { dan industri } \\
\text { kecil }\end{array}$ & $\begin{array}{l}\text { Kelanting } \\
\text { dan } \\
\text { Gulamerah }\end{array}$ & $\begin{array}{l}\text { Modal, peralatan } \\
\text { dan pembinaan } \\
\text { manajemen }\end{array}$ \\
\hline 11. & Purworejo & 142 & 105 & 233 & 258 & 138 & $\begin{array}{l}\text { Pengolahan } \\
\text { lahan } \\
\text { pertanian } \\
\text { dan } \\
\text { perkebunan }\end{array}$ & $\begin{array}{l}\text { Nira, padi } \\
\text { dan sayur- } \\
\text { sayuran }\end{array}$ & $\begin{array}{l}\text { SDM modal dan } \\
\text { peralatan }\end{array}$ \\
\hline 12. & $\begin{array}{l}\text { Kagungan } \\
\text { Ratu }\end{array}$ & 3 & 17 & 30 & 83 & 5 & $\begin{array}{l}\text { Pengolahan } \\
\text { lahan } \\
\text { pertanian } \\
\text { dan industri } \\
\text { kecil }\end{array}$ & $\begin{array}{l}\text { Padi dan } \\
\text { Tapis }\end{array}$ & $\begin{array}{l}\text { Modal dan } \\
\text { Peralatan }\end{array}$ \\
\hline 13. & Kalirejo & 53 & 38 & 41 & 111 & 13 & $\begin{array}{l}\text { Pengolahan } \\
\text { lahan } \\
\text { pertanian, } \\
\text { peternakan } \\
\text { dan industri } \\
\text { kecil }\end{array}$ & $\begin{array}{l}\text { Padi, telor } \\
\text { dan kerajinan } \\
\text { marmer }\end{array}$ & $\begin{array}{l}\text { Modal, peralatan } \\
\text { dan pemasaran }\end{array}$ \\
\hline 14. & $\begin{array}{l}\text { Tanjung } \\
\text { Rejo }\end{array}$ & 31 & 67 & 15 & 175 & 21 & $\begin{array}{l}\text { Pengolahan } \\
\text { Lahan } \\
\text { Pertanian } \\
\text { dan } \\
\text { Perkebunan }\end{array}$ & $\begin{array}{l}\text { Padi, Jagung } \\
\text { dan Karet }\end{array}$ & $\begin{array}{l}\text { SDA, modal dan } \\
\text { pemasaran }\end{array}$ \\
\hline 15. & $\begin{array}{l}\text { Halangan } \\
\text { Ratu }\end{array}$ & 37 & 80 & 35 & 77 & 19 & $\begin{array}{l}\text { Pengolahan } \\
\text { lahan } \\
\text { perkebunan } \\
\text { dan industri } \\
\text { kecil }\end{array}$ & $\begin{array}{l}\text { Karet dan } \\
\text { Tapis }\end{array}$ & $\begin{array}{l}\text { Modal dan } \\
\text { Peralatan }\end{array}$ \\
\hline 16. & Negara Saka & 66 & 79 & 72 & 161 & 5 & $\begin{array}{l}\text { Pengolahan } \\
\text { Industri } \\
\text { Kecil }\end{array}$ & $\begin{array}{l}\text { Genteng dan } \\
\text { meubeler }\end{array}$ & $\begin{array}{l}\text { Modal dan } \\
\text { peralatan }\end{array}$ \\
\hline 17. & $\begin{array}{l}\text { N. Ulangan } \\
\text { Jaya }\end{array}$ & 62 & 34 & 14 & 162 & 21 & $\begin{array}{l}\text { Pengolahan } \\
\text { lahan } \\
\text { pertanian } \\
\text { perkebunan } \\
\text { dan } \\
\text { peternakan }\end{array}$ & $\begin{array}{l}\text { Padi, coklat, } \\
\text { karet dan } \\
\text { ayam } \\
\text { pedaging }\end{array}$ & $\begin{array}{l}\text { Modal dan } \\
\text { Peralatan }\end{array}$ \\
\hline 18. & Pejambon & 44 & 45 & 79 & 114 & 12 & $\begin{array}{c}\text { Industri } \\
\text { Kecil }\end{array}$ & Genteng & $\begin{array}{l}\text { Modal,peralatan } \\
\text { dan manajemen }\end{array}$ \\
\hline 19. & $\begin{array}{l}\text { Negeri } \\
\text { Katon }\end{array}$ & 37 & 34 & 13 & 321 & 8 & $\begin{array}{c}\text { Pengolahan } \\
\text { lahan } \\
\text { perkebunan, } \\
\text { pertanian } \\
\text { dan industri } \\
\text { kecil }\end{array}$ & $\begin{array}{l}\text { Karet, jagung } \\
\text { dan tapis }\end{array}$ & Modal \\
\hline
\end{tabular}

komoditi melinjo yaitu 57,350 Ha, produktivitas terbesar pada komoditi sawi yaitu 921,95 Ku/Ha. Pada Komoditi Buah-Buahan produksi luas panen terbesar ada pada Komoditi Pisang yaitu 374.812 Ton dan 6.117.369 Ha. Produktivitas terbesar pada komoditi duku yaitu 13,27 Ku/Ha. Sedangkan produksi dan areal tanaman perkebunan terbesar ada pada komoditi kakao yaitu 9,538 Ton dan 15.062 Ha. Sedangkan produktivitas terbesar ada pada komoditi sawit yaitu 5,364 Kg/Ha. Produk domestik regional bruto (PDRB) di Kabupaten Pesawaran pada tahun 2011 sebesar 6.05 trilyun. Sektor pertanian dengan nilai PDRB sebesar 3 trilyun rupiah memberikan nilai PDRB terbesar di Kabupaten Pesawaran. Sektor 
Tabel 3. Perkembangan Ekonomi Masyarakat Kampung Suka Jawa.

\begin{tabular}{|c|c|c|c|c|}
\hline \multirow{2}{*}{ No } & \multirow{2}{*}{ Indikator } & \multirow{2}{*}{ Sub Indikator } & \multicolumn{2}{|c|}{ Jumlah } \\
\hline & & & Tahun 2010 & Tahun 2011 \\
\hline \multirow[t]{4}{*}{1.} & Pengangguran & 1. Jumlah penduduk usia kerja 15-56 tahun & 2551 orang & 2598 orang \\
\hline & & $\begin{array}{l}\text { 2. Jumlah penduduk usia kerja } 15-56 \text { tahun } \\
\text { tidak bekerja }\end{array}$ & 178 orang & 129 orang \\
\hline & & $\begin{array}{l}\text { 3. Penduduk wanita usia } 15-56 \text { tahun menjadi } \\
\text { ibu rumah tangga }\end{array}$ & 774 orang & 830 orang \\
\hline & & $\begin{array}{l}\text { 4. Jumlah penduduk usia }>15 \text { tahun yang cacat } \\
\text { sehingga tidak dapat bekerja }\end{array}$ & 7 orang & 7 orang \\
\hline \multirow[t]{7}{*}{2.} & Pendapatan & 1. pertanian & 1.941.285 orang & 5.989 .700 .000 orang \\
\hline & & 2. Kehutanan & 337.500 .000 orang & 394.400 .000 orang \\
\hline & & 3. Peternakan & 434.000 .000 orang & 512.840 .000 orang \\
\hline & & 4. Perikanan & 208.000 .000 orang & 176.000 .000 orang \\
\hline & & 5. Perdagangan & 4.987.250.000 orang & 5.236 .612 .000 orang \\
\hline & & 6. Jasa & 241.200 .000 orang & 258.084 .000 orang \\
\hline & & 7. Industri rumah tangga & 51.000 .000 orang & 57.120 .000 orang \\
\hline \multirow[t]{6}{*}{3.} & Tingkat & 1. Jumlah keluarga & $1031 \mathrm{kel}$ & $1.106 \mathrm{kel}$ \\
\hline & Kesejahteraan & 2. Jumlah keluarga pra sejahtera & $178 \mathrm{kel}$ & $134 \mathrm{kel}$ \\
\hline & & 3. Jumlah keluarga sejahtera 1 & $486 \mathrm{kel}$ & $596 \mathrm{kel}$ \\
\hline & & 4. Jumlah keluarga sejahtera 2 & $230 \mathrm{kel}$ & $237 \mathrm{kel}$ \\
\hline & & 5. Jumlah keluarga sejahtera 3 & $116 \mathrm{kel}$ & $116 \mathrm{kel}$ \\
\hline & & 6. Jumlah keluarga 3 plus & $21 \mathrm{kel}$ & $23 \mathrm{kel}$ \\
\hline
\end{tabular}

Sumber Data : Monografi Kampung Suka Jawa, 2012

Tabel4 . Jumlah perusahaan industri sedang-besar di Kabupaten Lampung Selatan.

\begin{tabular}{|c|c|c|}
\hline $\begin{array}{r}\text { Kode Industri } \\
\end{array}$ & Jumlah Perusahaan & Tenaga Kerja \\
\hline Industri makanan & 27 & 2913 \\
\hline Industri minuman & 1 & 121 \\
\hline Industri Pakaian Jadi & 5 & 278 \\
\hline $\begin{array}{l}\text { Industri Kayu, Barang dari Kayu dan Gabus, } \\
\text { anyaman dari bambu, rotan dan sejenisnya }\end{array}$ & 4 & 298 \\
\hline Industri kertas dan barang dari kertas & 1 & 191 \\
\hline $\begin{array}{l}\text { Industri produksi dari batubara dan } \\
\text { penggilangan minyak bumi }\end{array}$ & 1 & 27 \\
\hline $\begin{array}{l}\text { Industri bahan kimia dan barang dari bahan } \\
\text { kimia }\end{array}$ & 5 & 623 \\
\hline Industri karet, barang dari karet dan plastik & 2 & 156 \\
\hline Industri barang galian bukan logam & 6 & 416 \\
\hline $\begin{array}{l}\text { Industri barang dari logam bukan mesin dan } \\
\text { peralatan }\end{array}$ & 4 & 376 \\
\hline Industri mesin dan perlengkapan YTDL & 2 & 53 \\
\hline $\begin{array}{l}\text { Industri kendaraan bermotor, trailer dan semi } \\
\text { trailer }\end{array}$ & 3 & 173 \\
\hline Industri furnitur & 2 & 304 \\
\hline Industri pengolahan lainnya & 3 & 102 \\
\hline Jumlah & 66 & 6031 \\
\hline
\end{tabular}

Sumber data: Lampung Selatan Dalam Angka, 2012

dengan nilai PDRB terbesar kedua di Kabupaten Pesawaran adalah sektor perdagangan, hotel dan restoran. Nilai PDRB sektor ini adalah sebesar 991,96 milyar rupiah. Sektor industri pengolahan dengan dengan nilai PDRB sebesar 838,92 milyar rupiah merupakan sektor dengan nilai PDRB terbesar ketiga di Kabupaten Pesawaran. Sejalan perkembangannya pada usaha ekonomi keluarga di Kecamatan Negeri Katon Kabupaten Pesawaran dapat diamati pada tabel 2 .

Sedangkan perkembangan masyarakat di Kampung Suka Jawa Kabupaten Lampung Tengah, terinventarisir pada data yang terungkap dalam tabel 3.

Pada Kabupaten Lampung Selatan, jumlah perusahaan besar - sedang tahun 2011 sebanyak 66 perusahaan dengan total tenaga kerja 6.031 orang. Industri makanan merupakan industri dengan jumlah terbanyak di Kabupaten Lampung selatan serta industri yang paling banyak menyerap tenaga kerja bila dibandingkan dengan industri lainnya. Sebanyak $48,3 \%$ tenaga kerja di serap oleh industri makanan. Selengkapnya tertera tabel 4.

Terkait hal di atas, perkembangan usaha ekonomi keluarga masing-masing desa di Kabupaten Lampung Selatan dapat dilihat pada tabel 5.

\section{PEMBAHASAN}

Perkembangan kewirausahaan di lokasi sampel menjadi profesi utama yang digeluti oleh masyarakat desa. Seperti yang terjadi pada desa 
Tabel 5. Perkembangan Usaha Ekonomi Keluarga di Kabupaten Lampung Selatan.

\begin{tabular}{|c|c|c|c|c|c|c|c|c|c|}
\hline \multirow[b]{2}{*}{ No } & \multirow[b]{2}{*}{ Desa } & \multicolumn{5}{|c|}{ Jumlah Pelaku Usaha } & \multicolumn{2}{|c|}{ Jenis Usaha } & \multirow[b]{2}{*}{ Permasalahan } \\
\hline & & Jasa & Niaga & $\begin{array}{c}\text { Industri } \\
\text { Kecil }\end{array}$ & $\begin{array}{c}\text { Usaha } \\
\text { Tani }\end{array}$ & $\begin{array}{l}\text { Peter- } \\
\text { nakan }\end{array}$ & $\begin{array}{c}\text { Usaha } \\
\text { Dominan }\end{array}$ & $\begin{array}{c}\text { Produk } \\
\text { Unggulan } \\
\end{array}$ & \\
\hline 1. & Sidoasri & - & - & 4 & 1 & 2 & Industri RT & $\begin{array}{c}\text { Emping, } \\
\text { melinjo, } \\
\text { tahu }\end{array}$ & $\begin{array}{c}\text { Kekurangan } \\
\text { modal }\end{array}$ \\
\hline 2. & Hajimena & - & - & 3 & 1 & 2 & Industri RT & $\begin{array}{l}\text { Emping, } \\
\text { Sulaman }\end{array}$ & $\begin{array}{l}\text { Kekurangan } \\
\text { Modal }\end{array}$ \\
\hline 3. & Pemanggilan & - & - & 3 & 1 & 2 & Industri RT & $\begin{array}{l}\text { Keripik } \\
\text { pisang, } \\
\text { sulaman }\end{array}$ & $\begin{array}{l}\text { Kekurangan } \\
\text { modal }\end{array}$ \\
\hline 4. & Natar & - & - & 4 & 2 & 2 & Industri RT & $\begin{array}{l}\text { Sulam usus } \\
\text { dan tapis }\end{array}$ & $\begin{array}{l}\text { Kekurangan } \\
\text { modal }\end{array}$ \\
\hline 5. & Muara putih & - & - & 2 & 2 & 2 & $\begin{array}{c}\text { Usaha } \\
\text { pertanian }\end{array}$ & $\begin{array}{l}\text { Produk } \\
\text { pertanian }\end{array}$ & Lahan kering \\
\hline 6. & Merakbatin & - & - & 4 & 2 & 2 & $\begin{array}{l}\text { Usaha } \\
\text { pertanian }\end{array}$ & $\begin{array}{l}\text { Produk } \\
\text { pertanian }\end{array}$ & Lahan kering \\
\hline 7. & $\begin{array}{l}\text { Krawang } \\
\text { sari }\end{array}$ & - & - & 3 & 3 & 2 & Peternakan & $\begin{array}{c}\text { Peternakan, } \\
\text { pertanian }\end{array}$ & $\begin{array}{l}\text { Kekurangan } \\
\text { modal }\end{array}$ \\
\hline 8. & Negara ratu & - & - & 4 & 2 & 2 & $\begin{array}{l}\text { Indsutri } \\
\text { gerabah }\end{array}$ & $\begin{array}{l}\text { Gerabah, } \\
\text { keramik }\end{array}$ & $\begin{array}{l}\text { Kekurangan } \\
\text { modal }\end{array}$ \\
\hline 9. & Rejoasri & - & - & 2 & 2 & 1 & Industri RT & $\begin{array}{c}\text { Tahu dan } \\
\text { kripik }\end{array}$ & $\begin{array}{l}\text { Kekurangan } \\
\text { modal }\end{array}$ \\
\hline 10. & Tanjung asri & - & - & 3 & 2 & 1 & Industri RT & Meubel & $\begin{array}{l}\text { Kekurangan } \\
\text { modal }\end{array}$ \\
\hline 11. & Bumisari & - & - & 3 & 2 & 1 & Industri RT & $\begin{array}{c}\text { Makanan } \\
\text { ringan }\end{array}$ & $\begin{array}{l}\text { Kekurangan } \\
\text { modal }\end{array}$ \\
\hline 12. & Candimas & - & - & 4 & 2 & 2 & Industri RT & $\begin{array}{c}\text { Makanan } \\
\text { ringan }\end{array}$ & $\begin{array}{l}\text { Kekurangan } \\
\text { modal }\end{array}$ \\
\hline 13. & Branti raya & - & - & 3 & 2 & 2 & Industri RT & $\begin{array}{l}\text { Kerupuk } \\
\text { singkong }\end{array}$ & $\begin{array}{l}\text { Kekurangan } \\
\text { modal }\end{array}$ \\
\hline 14. & Haduyang & - & - & 3 & 2 & 2 & Industri RT & Sulam tapis & $\begin{array}{c}\text { Kekurangan } \\
\text { modal }\end{array}$ \\
\hline 15. & $\begin{array}{l}\text { Banjar } \\
\text { negeri }\end{array}$ & - & - & 2 & 2 & 2 & Industri RT & Sulam tapis & $\begin{array}{l}\text { Kekurangan } \\
\text { modal }\end{array}$ \\
\hline 16. & Mandah & - & - & 3 & 2 & 1 & $\begin{array}{c}\text { Usaha } \\
\text { pertanian }\end{array}$ & $\begin{array}{l}\text { Produk } \\
\text { sayuran }\end{array}$ & $\begin{array}{c}\text { Kekurangan } \\
\text { modal }\end{array}$ \\
\hline 17. & $\begin{array}{l}\text { Rulung } \\
\text { helok }\end{array}$ & - & - & 2 & 2 & 1 & Industri RT & Gula merah & $\begin{array}{l}\text { Kekurangan } \\
\text { modal }\end{array}$ \\
\hline 18. & Rulung raya & - & - & 3 & 2 & 2 & Peternakan & $\begin{array}{c}\text { Peternakan } \\
\text { ayam }\end{array}$ & $\begin{array}{l}\text { Kekurangan } \\
\text { modal }\end{array}$ \\
\hline 19. & Purwosari & - & - & 2 & 2 & 1 & $\begin{array}{c}\text { Usaha } \\
\text { pertanian }\end{array}$ & $\begin{array}{l}\text { Produk } \\
\text { pertanian }\end{array}$ & $\begin{array}{l}\text { Kekurangan } \\
\text { modal }\end{array}$ \\
\hline 20. & Pancasila & - & - & 2 & 2 & 2 & Palawija & Sayuran & $\begin{array}{l}\text { Kekurangan } \\
\text { modal }\end{array}$ \\
\hline 21. & Bandarejo & - & - & 2 & 2 & 1 & $\begin{array}{c}\text { Usaha } \\
\text { pertanian }\end{array}$ & $\begin{array}{c}\text { Produk } \\
\text { pertanian }\end{array}$ & $\begin{array}{l}\text { Kekurangan } \\
\text { modal }\end{array}$ \\
\hline 22. & Sukadamai & - & - & 3 & 2 & 1 & Industri RT & $\begin{array}{l}\text { Klanting, } \\
\text { anyaman }\end{array}$ & $\begin{array}{l}\text { Kekurangan } \\
\text { modal }\end{array}$ \\
\hline
\end{tabular}

Karang Rejo, Desa Sidoasri dan Kampung suka jawa. Selaras dengan kenyataan di lapangan informan menuturkan potensi-potensi yang dimiliki dalam pengembangan kewirausahaan desa terdapat pada Tabel 6.

Tabel 6. Potensi Pengembangan Kewirausahaan Desa.

\begin{tabular}{lll}
\hline \multirow{2}{*}{ Desa/Kecamatan/Kab } & \multicolumn{2}{c}{ Informan } \\
\cline { 2 - 3 } & \multicolumn{1}{c}{$\begin{array}{c}\text { Pemerintah } \\
\text { Daerah }\end{array}$} & $\begin{array}{c}\text { Pemerintah } \\
\text { Desa }\end{array}$ \\
\hline Kampung Suka Jawa & Usaha & $\begin{array}{l}\text { Pembuatan } \\
\text { Kecamatan Bumiratu }\end{array}$ \\
masyarakat & lanting, pisang \\
Nuban Kabupaten & menonjol seperti & coklat aneka \\
Lampung Tengah & variasi mobil, & rasa \\
& perbengkelan di & \\
& desa sukajawa, & \\
& usaha kripik & \\
& pisang coklat & \\
\end{tabular}

\begin{tabular}{|c|c|c|}
\hline $\begin{array}{l}\text { Desa Karang Rejo } \\
\text { Kecamatan Negeri } \\
\text { Katon Kabupaten } \\
\text { Pesawaran }\end{array}$ & $\begin{array}{l}\text { Perkembangan } \\
\text { kewirausahaan } \\
\text { disini khususnya } \\
\text { Desa Karangrejo } \\
\text { sudah ada } \\
\text { pengusaha yang } \\
\text { jumlahnya } 5495 \\
\text { orang pelaku } \\
\text { usaha yang } \\
\text { bergerak di } \\
\text { bidang jasa, } \\
\text { niaga, industri } \\
\text { kecil, usaha tani, } \\
\text { peternakan yang } \\
\text { masing-maisng } \\
\text { pengusaha } \\
\text { memiliki } \\
\text { kendala masing- } \\
\text { masing. }\end{array}$ & $\begin{array}{l}\text { Sangkar } \\
\text { burung, kopra } \\
\text { usaha skala }\end{array}$ \\
\hline $\begin{array}{l}\text { Desa Sindoasri } \\
\text { Kecamatan Candipuro } \\
\text { Kabupaten Lampung }\end{array}$ & $\begin{array}{l}\text { Banyak usaha } \\
\text { yang ada di } \\
\text { Candi puro }\end{array}$ & $\begin{array}{l}\text { Kripik } \\
\text { kemplang, } \\
\text { usaha kripik }\end{array}$ \\
\hline
\end{tabular}




\begin{tabular}{lll} 
Selatan & sekitar 43 & pisang, \\
& pelaku usaha & furniture, dsb \\
& dan terkategori & \\
& usaha kecil & \\
& seperti bidang & \\
pertanian, & \\
perdagangan, dll & \\
\hline
\end{tabular}

Sumber Data : Data Primer, 2012.

Mencermati kondisi tabel di atas, potensi wirausaha di desa memang layak untuk dikembangkan. Dan sebagian masyarakat memanfatkan SDA yang ada di desa, meskipun memasok bahan baku produksinya dari luar desa, itupun dikarenakan kelangkaan bahan baku yang mereka butuhkan.

Secara prinsipil program kewirausahaan desa yang ada disesuaikan dengan potensi muda yang ada di lokasi sampel.

Tabel 7. Program Kewirausahaan Relevan dengan Potensi Kaum Muda.

\begin{tabular}{|c|c|c|}
\hline \multirow[b]{2}{*}{$\begin{array}{c}\text { Desa/Kecamatan/ } \\
\text { Kabupaten }\end{array}$} & \multicolumn{2}{|c|}{ Informan } \\
\hline & $\begin{array}{l}\text { Pemerintah } \\
\text { Daerah }\end{array}$ & $\begin{array}{c}\text { Pemerintah } \\
\text { Desa }\end{array}$ \\
\hline $\begin{array}{l}\text { Kampung Suka Jawa } \\
\text { Kecamatan Bumiratu } \\
\text { Nuban Kabupaten } \\
\text { Lampung Tengah }\end{array}$ & $\begin{array}{l}\text { Ya sesuai } \\
\text { dengan potensi } \\
\text { yang ada } \\
\text { hanya kadang } \\
\text { pengusaha } \\
\text { disini } \\
\text { menyesuaikan } \\
\text { juga dengan } \\
\text { bakat } \\
\text { kemampuanny } \\
\text { a untuk } \\
\text { mengolah }\end{array}$ & $\begin{array}{l}\text { Belum sesuai } \\
\text { buktinya } \\
\text { bnyak } \\
\text { pemuda yang } \\
\text { pergi } \\
\text { meninggalka } \\
\text { n desa ini }\end{array}$ \\
\hline $\begin{array}{l}\text { Desa Karang Rejo } \\
\text { Kecamatan Negeri Katon } \\
\text { Kabupaten Pesawaran }\end{array}$ & $\begin{array}{l}\text { Yang pasti } \\
\text { disesuaikan } \\
\text { dengan } \\
\text { keahlian } \\
\text { masing- } \\
\text { masing } \\
\text { masyarakat } \\
\text { bukan hanya } \\
\text { pemuda, } \\
\text { pemuda hanya } \\
\text { sebagian kecil } \\
\text { yang turut } \\
\text { andil dalam } \\
\text { setiap usaha } \\
\text { masyarakat. }\end{array}$ & $\begin{array}{l}\text { Tidak ada } \\
\text { semuanya } \\
\text { usaha karena } \\
\text { disesuaikan } \\
\text { dengan } \\
\text { permintaan } \\
\text { pasar dan } \\
\text { justru anak } \\
\text { mudanya } \\
\text { pada ke kota } \\
\text { karena } \\
\text { tingkat } \\
\text { pendidikan } \\
\text { mereka } \\
\text { rendah }\end{array}$ \\
\hline $\begin{array}{l}\text { Desa Sindoasri Kecamatan } \\
\text { Candipuro Kabupaten } \\
\text { Lampung Selatan }\end{array}$ & $\begin{array}{l}\text { Anak muda } \\
\text { justru tidak } \\
\text { tertarik dengan } \\
\text { usaha yang } \\
\text { ada disini }\end{array}$ & $\begin{array}{l}\text { Masih dicoba } \\
\text { dan pemuda } \\
\text { secara umum } \\
\text { cari } \\
\text { pekerjaan di } \\
\text { luar. }\end{array}$ \\
\hline
\end{tabular}

Sumber Data : Data Primer, 2012

Berdasarkan tabel di atas, peluang usaha yang ada di desa tidak sepenuhnya mengakomodir kaum muda. Pengusaha lebih dominan mengikuti permintaan pasar, dan peran serta pemuda dalam mendongkrak usaha di desa hanya sebagian kecil saja.
Sebagai pengusaha yang menjadi leader dalam menjalankan usahanya dianggap sebagai pribadi yang memiliki sejuta gagasan dan ide untuk menciptakan kreativitas dan inovasi dalam mengembangkan usahanya. Guna melihat mentalitas pengusaha di masing-masing sampel dapat dilihat pada tabel berikut ini :

Tabel 8 . Mentalitas Pengusaha di Lokasi Sampel.

\begin{tabular}{|c|c|c|}
\hline \multirow[b]{2}{*}{$\begin{array}{c}\text { Desa/Kecamatan/ } \\
\text { Kabupaten }\end{array}$} & \multicolumn{2}{|c|}{ Informan } \\
\hline & $\begin{array}{c}\text { Pemerintah } \\
\text { Daerah }\end{array}$ & $\begin{array}{c}\text { Pemerintah } \\
\text { Desa }\end{array}$ \\
\hline $\begin{array}{l}\text { Kampung Suka } \\
\text { Jawa Kecamatan } \\
\text { Bumiratu Nuban } \\
\text { Kabupaten } \\
\text { Lampung Tengah }\end{array}$ & $\begin{array}{l}\text { Ya, itu kunci mati } \\
\text { buat mereka yang } \\
\text { harus terus } \\
\text { ditingkatkan }\end{array}$ & $\begin{array}{l}\text { Ya, harus } \\
\text { seperti itu } \\
\text { karena seorang } \\
\text { pengusaha } \\
\text { harus penuh } \\
\text { dengan kreasi }\end{array}$ \\
\hline $\begin{array}{l}\text { Desa Karang Rejo } \\
\text { Kecamatan Negeri } \\
\text { Katon Kabupaten } \\
\text { Pesawaran }\end{array}$ & $\begin{array}{l}\text { Secara umum iya } \\
\text { mereka kreativ } \\
\text { dan ide-idenya } \\
\text { yang unik untuk } \\
\text { menarik } \\
\text { konsumen }\end{array}$ & $\begin{array}{l}\text { Ada, misalnya } \\
\text { lanting } \\
\text { ditambah } \\
\text { rasanya } \\
\text { sehingga } \\
\text { variatif }\end{array}$ \\
\hline $\begin{array}{l}\text { Desa Sindoasri } \\
\text { Kecamatan } \\
\text { Candipuro } \\
\text { Kabupaten } \\
\text { Lampung Selatan }\end{array}$ & $\begin{array}{l}\text { Iya, tentunya } \\
\text { karena pada } \\
\text { dasarnya mereka } \\
\text { berjiwa } \\
\text { pengusaha }\end{array}$ & $\begin{array}{l}\text { Ya, berjiwa } \\
\text { kreatif dan } \\
\text { berani } \\
\text { mengambil } \\
\text { resiko }\end{array}$ \\
\hline
\end{tabular}

Selaras dengan tabel di atas, dapat dikemukakan bahwa pengusaha yang ada di lokasi sampel selain memiliki skill dan kompetensi yang handal, tetapi juga mentalitas nya sebagai pelaku usaha profesional sudah ditunjukkannya. Mereka memiliki rasa, karsa dan yang terpenting adalah kreasi dan inovasi untuk terus menerus mencari temuan baru yang dapat memajukan usahanya.

Sejalan dengan upaya untuk mengembangkan kewirausahaan di desa, pelaksanaan fasilitasi untuk program usaha yang sedang digalakkan oleh desa menjadikan suatu keharusan yang sepatutnya mendapat atensi dari pemerintah daerah ataupun pemerintah desa. Selengkapnya seperti tertera pada tabel di bawah ini :

Tabel 9. Pelaksanaan Fasilitasi dalam Program Kewirausahaan di Desa.

\begin{tabular}{|c|c|c|}
\hline \multirow[b]{2}{*}{$\begin{array}{c}\text { Desa/Kecamatan/ } \\
\text { Kabupaten }\end{array}$} & \multicolumn{2}{|c|}{ Informan } \\
\hline & $\begin{array}{l}\text { Pemerintah } \\
\text { Daerah }\end{array}$ & Pemerintah Desa \\
\hline $\begin{array}{l}\text { Kampung Suka } \\
\text { Jawa Kecamatan } \\
\text { Bumiratu Nuban } \\
\text { Kabupaten } \\
\text { Lampung Tengah }\end{array}$ & $\begin{array}{l}\text { Untuk pelatihan } \\
\text { ternak misalnya } \\
50 \text { orang dilatih } 1 \\
\text { kecamatan } 3 \\
\text { kelurahan }\end{array}$ & $\begin{array}{l}\text { Kewirausahaan } \\
\text { desa masih } \\
\text { berupa pelatihan } \\
\text { yang dilakukan } \\
\text { oleh Provinsi }\end{array}$ \\
\hline $\begin{array}{l}\text { Desa Karang Rejo } \\
\text { Kecamatan Negeri } \\
\text { Katon Kabupaten } \\
\text { Pesawaran }\end{array}$ & $\begin{array}{l}\text { Untuk pelatihan } \\
\text { dilakukan di } \\
\text { provinsi, } \\
\text { kabupaten hanya } \\
\text { memfasilitasi } \\
\text { mengirim } \\
\text { perwakilan yang }\end{array}$ & $\begin{array}{l}\text { Pelatihan ada } \\
\text { yang dikirim bagi } \\
\text { mereka yang } \\
\text { sudah punya } \\
\text { usaha }\end{array}$ \\
\hline
\end{tabular}




\begin{tabular}{lll} 
& akan menjadi \\
& peserta di \\
& pelatihan \\
& tersebut. & \\
Desa Sindoasri & Dari & Pelatihan saja \\
Kecamatan & Kabupaten/Provi & \\
Candipuro & nsi, untuk & \\
Kabupaten & kecamatan candi \\
Lampung Selatan & puro belum \\
& pernah \\
& memperoleh \\
& pelatihan, entah \\
& di kecamatan \\
& lainnya, tapi \\
& kalau pameran \\
& kami sering \\
& mengadakannya \\
\hline
\end{tabular}

Sumber Data : Data Primer, 2012

Pengakuan informan dari tabel di atas menyiratkan bahwa Pemerintah daerah dan pemerintah desa memfasilitasi pelatihan yang dilakukan kepada para pelaku usaha. Dengan cara membuat usulan-usulan peserta yang akan dikirim untuk mengikuti pelatihan.

Keterlibatan tokoh masyarakat di desa sangat urgen dalam mengembangkan kewirausahaan di desa, apalagi komitmen dan kekonsistenan mereka menjadikan mata rantai yang tidak bisa dilepaskan dari pengembangan kewirausahaan desa. Selengkapnya dapat dilihat pada tabel di bawah ini :

Tabel 10. Konsistenan Tokoh Masyarakat dalam MengembangkanKewirausahaan Desa.

\begin{tabular}{|c|c|}
\hline $\begin{array}{c}\text { Desa/Kecamatan/ } \\
\text { Kabupaten }\end{array}$ & $\begin{array}{c}\text { Informan } \\
\text { Pemerintah Desa }\end{array}$ \\
\hline $\begin{array}{l}\text { Kampung Suka Jawa } \\
\text { Kecamatan Bumiratu Nuban } \\
\text { Kabupaten Lampung Tengah }\end{array}$ & $\begin{array}{l}\text { Harapan sih ada bagi para } \\
\text { pemimpin di desa ini untuk } \\
\text { mengembangkan usaha di } \\
\text { desa, Cuma kendalanya kan } \\
\text { anggaran kita sangat terbatas } \\
\text { paling hanya sekedar } \\
\text { motivasi }\end{array}$ \\
\hline Desa Karang Rejo & Untuk pembinaan sangat \\
\hline Kecamatan Negeri Katon & kurang karena kesibukan \\
\hline Kabupaten Pesawaran & $\begin{array}{l}\text { masing-masing sehingga } \\
\text { mereka tidak ada pembinaan } \\
\text { secara khusus }\end{array}$ \\
\hline $\begin{array}{l}\text { Desa Sindoasri Kecamatan } \\
\text { Candipuro Kabupaten }\end{array}$ & $\begin{array}{l}\text { Ya berupa pengusulan nama } \\
\text { pelaku usaha untuk }\end{array}$ \\
\hline Lampung Selatan & $\begin{array}{l}\text { dilibatkan apabila pemeritah } \\
\text { melakukan pelatihan. }\end{array}$ \\
\hline
\end{tabular}

Sumber Data : Data Primer, 2012.

Pada tabel konsistenan tokoh masyarakat, pada dasarnya mereka memiliki harapan untuk memajukan kewirausahaan, hanya untuk Desa Karang Rejo Kabupaten Pesawaran tokoh masyarakat kurang intensif dalam menyikapi wirausaha yang ada di desa.

Selain itu dalam penyajian hasil wawancara berikut, upaya pemerintah secara intensif dalam mengembangkan kewirausahaan di desa dapat disimak pada penuturan informan di wilayah sampel berikut ini :
Tabel 11. Upaya Pemerintah Dalam Mengembangkan Kewirausahaan Desa.

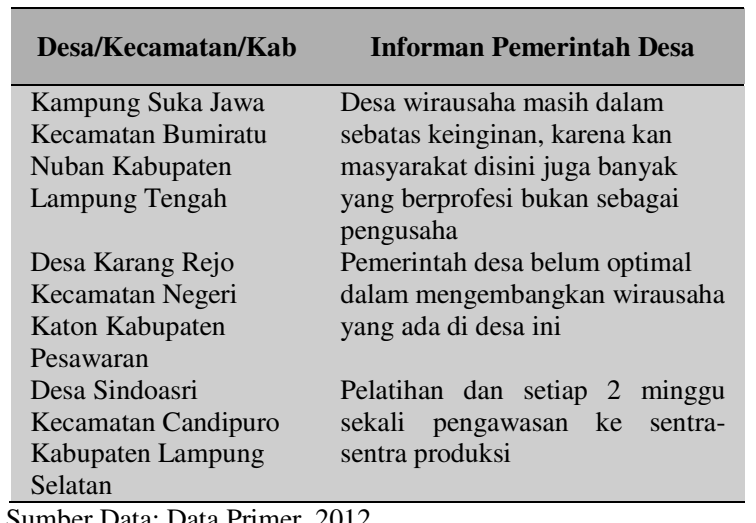

Mayoritas informan mengatakan bahwa Pemerintah Desa dalam mengembangkan kewirausahaan di desa kurang optimal, kecuali untuk Desa Sindosari Kecamatan Candir Puro Kabupaten Lampung Selatan Kepala Desa melakukan pengawasan ke pusat-pusat produksi.

Pengembangan kewirausahaan desa tidak hanya melibatkan tokoh masyarakat ataupun pemerintah desa, tetapi lebih kepada respon masyarakat sekitar terhadap tumbuh kembangnya wirausaha di sekitar wilayahnya. Lebih lengkapnya sebagai berikut :

Tabel 12 . Pelibatan Masyarakat dalam Mengembangkan Kewirausahaan Desa.

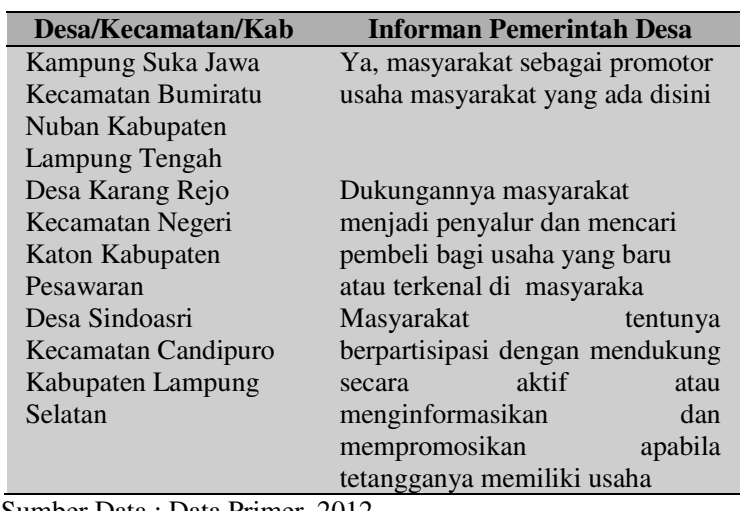

Masyarakat sekitar memberikan dukungan penuh kepada pelaku usaha seperti yang tertera pada tabel di atas, bahkan dukungan masyarakat tersebut sekaligus memberikan keuntungan bagi pengusaha karena masyarakat menjadi promotor yang baik dalam memperkenalkan produk yang di tawarkannya.

Keterlibatan pemerintah daerah menjadi atensi yang sangat tinggi terhadap para pelaku usaha, apalagi pemerintah daerah menganggap bahwa usaha-usaha yang ada di desa menjadi instrumen untuk mendongkrak bangkitnya masyarakat desa untuk merubah garis perekonomiannya. Lebih lengkapnya dapat dilihat pada tabel berikut ini : 
Tabel 13. Keterlibatan Pemerintah Daerah Dalam Memajukan Pelaku Usaha

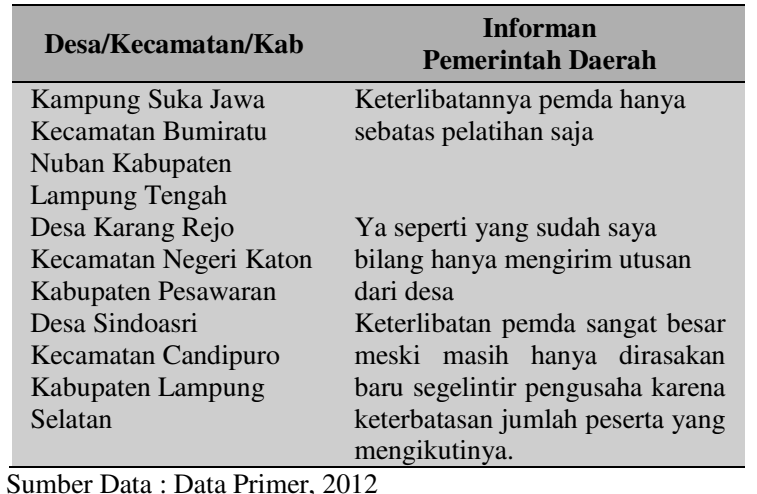

Peran serta Pemerintah Daerah yang tinggi dalam mengembangkan kewirausahaan desa dicapai melalui pelatihan-pelatihan ataupun mengusulkan peserta pelatihan kepada Pemerintah Provinsi. Pengiriman peserta tersebut disesuaikan dengan permintaan dari Pemerintah Provinsi dan mayoritas mereka yang mengikuti adalah masyarakat yang telah memiliki usaha ataupun masyarakat yang hanya sekedar memiliki keinginan untuk berwirausaha.

Setiap program sudah dipastikan akan menemui kendala, dan setiap kendala itu akan menjadi kekuatan untuk memajukan usaha terutama bagi pelaku usaha maupun pengambil kebijakan yang terlibat secara aktif dalam mengembangkan kewirausahaan di desa. Oleh karena itu pengakuan informan pada tabel 14
Tabel 14. Hambatan dalam Pengembangan Kewirausahaan di Desa.

\begin{tabular}{|c|c|}
\hline Desa/Kecamatan/Kab & Informan Pemerintah Daerah \\
\hline $\begin{array}{l}\text { Kampung Suka Jawa } \\
\text { Kecamatan Bumiratu } \\
\text { Nuban Kabupaten } \\
\text { Lampung Tengah }\end{array}$ & $\begin{array}{l}\text { Krisis kepercayaan untuk } \\
\text { memperoleh dana dari } \\
\text { masyarakat }\end{array}$ \\
\hline $\begin{array}{l}\text { Desa Karang Rejo } \\
\text { Kecamatan Negeri Katon } \\
\text { Kabupaten Pesawaran } \\
\text { Desa Sindoasri Kecamatan } \\
\text { Candipuro Kabupaten } \\
\text { Lampung Selatan }\end{array}$ & $\begin{array}{l}\text { Hambatannya terletak pada } \\
\text { anggaran yang terbatas untuk } \\
\text { memberdayakan mereka } \\
\text { Hambatannya Pengusaha lebih } \\
\text { matrialistis dan perhitungan } \\
\text { bisnis dan untuk menyadarkan } \\
\text { mereka untuk dilatih sangatlah } \\
\text { sulit karena perhitungan untung } \\
\text { rugi bila mereka mengikuti } \\
\text { pelatihan. Kendalanya jadi } \\
\text { kesadaran dan pemikiran } \\
\text { masyarakat sangat tradisional } \\
\text { untuk mengikuti pelatihan }\end{array}$ \\
\hline
\end{tabular}

Sumber Data : Data Primer, 2012

Membaca tabel di atas, hambatan yang dihadapi oleh informan terletak pada faktor internal dan eksternal. Faktor Internal menunjukkan egosentris pengusaha untuk menggali skill nya dan ketersediaan anggaran yang terbatas untuk memberdayakan pelaku usaha.

Pelatihan yang secara kontinuitas dilakukan oleh pemerintah daerah ataupun pemerintah provinsi menjadi momentum awal bagi masyarakat yang menjadi pelaku usaha untuk menjadikan usahanya lebih baik dari sebelumnya. Berikut tabel akan menguraikan lebih terperinci informasi yang disampaikan pelaku usaha pada tabel 15 .

Tabel 15. Penyelenggaraan Pelatihan

\begin{tabular}{|c|c|c|c|}
\hline \multirow{2}{*}{ Desa/Kecamatan/ Kab } & \multicolumn{3}{|c|}{ Informan } \\
\hline & 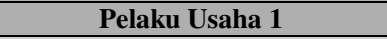 & Pelaku Usaha II & Pelaku Usaha III \\
\hline Kampung Suka Jawa & Iya pelatihan seperti sertifikasi & Pelatihan dari Dinas & BRI, Dinas pertanian, \\
\hline Kecamatan Bumiratu Nuban & produksi pangan industri rumah & Pertanian di Hotel & ASPINDO \\
\hline Kabupaten Lampung Tengah & $\begin{array}{l}\text { tangga untuk jenis produksi } \\
\text { kripik pisang dan sale pisang, } \\
\text { kunyit instant, temulawak } \\
\text { instant, beras kencur instant serta } \\
\text { sosialisasi dan pembinaan } \\
\text { pengobatan alternatif } \\
\text { menggunakan tumbuhan (herba) } \\
\text { dan refleksi, Pelatihan dari } \\
\text { Unila dan Dewan Riset Daerah }\end{array}$ & $\begin{array}{l}\text { Marcopolo, management } \\
\text { usaha diklat di BRI Pusat } \\
\text { dengan dibiayai } 6 \text { juta, } \\
\text { aspindo selama } 1 \text { minggu }\end{array}$ & \\
\hline Desa Karang Rejo Kecamatan & Pelatihan untuk penggunaan & Ada, Pelatihan untuk & Kalau ada ikut Provinsi di \\
\hline Negeri Katon Kabupaten & pewarna karena lanting ini kan & penggunaan pewarna karena & Jogja di balai besar tahun 2007 \\
\hline Pesawaran & $\begin{array}{l}\text { tidak hanya berwarna putih tapi } \\
\text { ada yang berwarna merah }\end{array}$ & $\begin{array}{l}\text { lanting ini kan tidak hanya } \\
\text { berwarna putih tapi ada yang } \\
\text { berwarna merah }\end{array}$ & \\
\hline Desa Sindoasri Kecamatan & Pelatihannya hanya mempelajari & Ya, Sertifikasi dari & Pelatihan belum pernah sama \\
\hline Candipuro Kabupaten & permintaan pasar dan pelatihan & Departemen Kesehatan dan & sekali \\
\hline Lampung Selatan & $\begin{array}{l}\text { manajemen tahun } 2011 \text {, } \\
\text { penyelenggaranya Pemerintah } \\
\text { Kabupaten }\end{array}$ & SIUP & \\
\hline
\end{tabular}

Sumber Data : Data Primer, 2012 
Tabel 16 . Keahlian Pelaku Usaha.

\begin{tabular}{|c|c|c|c|}
\hline \multirow{2}{*}{ Desa/Kecamatan/ Kab } & \multicolumn{3}{|c|}{ Informan } \\
\hline & $\begin{array}{l}\text { Pelaku Usaha } 1 \\
\end{array}$ & Pelaku Usaha II & Pelaku Usaha III \\
\hline $\begin{array}{l}\text { Kampung Suka Jawa } \\
\text { Kecamatan Bumiratu } \\
\text { Nuban Kabupaten } \\
\text { Lampung Tengah }\end{array}$ & $\begin{array}{l}\text { Harus memiliki kemampuan } \\
\text { untuk meracik }\end{array}$ & Keterampilan tangan & $\begin{array}{l}\text { Ketrampilannya keuletan } \\
\text { dan kerja keras }\end{array}$ \\
\hline $\begin{array}{l}\text { Desa Karang Rejo } \\
\text { Kecamatan Negeri Katon } \\
\text { Kabupaten Pesawaran }\end{array}$ & $\begin{array}{l}\text { Kemampuannya ya ulet aja } \\
\text { dan tidak mengurangi rasa } \\
\text { lanting }\end{array}$ & $\begin{array}{l}\text { Cenderung koneksi } \\
\text { sedangkan untuk keahlian } \\
\text { cenderung semua orang } \\
\text { bisa karena untuk } \\
\text { menetralisir asam dan } \\
\text { kebutuhannya sangat tinggi } \\
\text { sifatnya dari batu kapur }\end{array}$ & $\begin{array}{l}\text { Keahlian didapat dari } \\
\text { lingkungan yaitu } \\
\text { kreativitas }\end{array}$ \\
\hline $\begin{array}{l}\text { Desa Sindoasri Kecamatan } \\
\text { Candipuro Kabupaten } \\
\text { Lampung Selatan }\end{array}$ & Mengamati selera pasar aja & $\begin{array}{l}\text { Prospek bagus dan } \\
\text { awalnya jual pisang sale } \\
\text { dilihat bnyak pesanan } \\
\text { akhirnya sekarang kripik } \\
\text { pisang sudah beraneka rasa } \\
\text { strawbery, balado, coklat, } \\
\text { keju, melon, durian, } \\
\text { mocca, coco coffe, susu, } \\
\text { manis. }\end{array}$ & $\begin{array}{l}\text { Kemampuan mengolah } \\
\text { antara tepung tapioka dan } \\
\text { ikan gabus laut. }\end{array}$ \\
\hline
\end{tabular}

Tabel 17. Pemagangan Pelaku Usaha.

\begin{tabular}{|c|c|c|c|}
\hline \multirow{2}{*}{ Desa/Kecamatan/Kab } & \multicolumn{3}{|c|}{ Informan } \\
\hline & Pelaku Usaha 1 & Pelaku Usaha II & Pelaku Usaha III \\
\hline $\begin{array}{l}\text { Kampung Suka Jawa } \\
\text { Kecamatan Bumiratu } \\
\text { Nuban Kabupaten } \\
\text { Lampung Tengah }\end{array}$ & Belum & $\begin{array}{l}\text { Studi banding ke } \\
\text { Pesawaran }\end{array}$ & Belum Ada \\
\hline $\begin{array}{l}\text { Desa Karang Rejo } \\
\text { Kecamatan Negeri Katon } \\
\text { Kabupaten Pesawaran }\end{array}$ & $\begin{array}{l}\text { Pemagangan dari Dinas } \\
\text { Kesehatan }\end{array}$ & $\begin{array}{l}\text { Belum pernah semuanya } \\
\text { otodidak }\end{array}$ & $\begin{array}{l}\text { Magangnya di Jogja di } \\
\text { perusahaan keramik “ } \\
\text { Bejo Keramik” Desa } \\
\text { Kasongan }\end{array}$ \\
\hline $\begin{array}{l}\text { Desa Sindoasri } \\
\text { Kecamatan Candipuro } \\
\text { KabLampung Sel }\end{array}$ & $\begin{array}{l}\text { Dinas pertanian hanya } \\
\text { packaging }\end{array}$ & Belum pernah & $\begin{array}{l}\text { Ya, Kerja di bandar } \\
\text { lampung selama } 15 \text { tahun }\end{array}$ \\
\hline
\end{tabular}

Pelatihan yang dilakukan oleh Pemerintah dalam menggali potensi pelaku usaha sangat relevan dengan kebutuhan para pelaku usaha. Pengetahuan yang diperoleh di pelatihan tersebut menjadikan bekal buat pelaku usaha untuk mengembangkan usahanya secara maksimal.

Untuk menjadi pengusaha dituntut memiliki keahlian yang mampu mendukung usahanya, dan tidak semua orang akan mampu memiliki keahlian si pengusaha. Untuk melihat keahlian pelaku usaha di lokasi sampel, dapat dilihat pada uraian pada tabel 16.

Dari apa yang terungkap pada tabel, informan menuturkan bahwa untuk keahlian yang masingmasing dimiliki oleh informan secara implisit bekal bagi pengusaha untuk mengembangkan usaha yang ditekuninya. Meski beragam keahlian yang dimiliki para pengusaha namun menunjukkan bahwa untuk menjadikan usaha berkembang, para pengusaha dapat menekuni profesinya secara profesional dan mampu memiliki manajemen usaha yang baik.
Selain pelatihan, pemagangan menjadi penting tatkala para pengusaha membutuhkan pencerahan dan masukan yang terkait dengan usahanya. Sistim pemagangan yang dilakukan para pengusaha, akan mempengaruhi skill maupun pola produksinya. Selengkapnya tertera pada tabel 17.

Mengamati perkembangan pada tabel di atas, menyiratkan bahwa pengalaman yang berperan dalam diri pengusaha untuk menjalankan profesinya. Dimana mayoritas informan belum pernah melakukan pemagangan, dan meskipun ada yang melakukan pemagangan para pelaku dapat memanfaatkan ilmu yang diperolehnya untuk menjadikan usahanya lebih baik.

Selaras dengan keinginan untuk mengembangkan kewirausahaan di desa, peran pemerintah sangalah penting untuk melihat atensi para pengambil kebijakan. Selengkapnya dapat dilihat pada tabel 18. Dari apa yang dikemukakan di atas, diketahui bahwa Pemerintah hanya membimbing pelaku usaha melalui pelatihan saja, dan tidak sampai pada tahap pedampingan. Informan 
Tabel 18. Pembimbingan dan Pedampingan oleh Pemerintah.

\begin{tabular}{|c|c|c|c|}
\hline \multirow{2}{*}{ Desa/Kecamatan/Kabupaten } & \multicolumn{3}{|c|}{ Informan } \\
\hline & Pelaku Usaha 1 & Pelaku Usaha II & Pelaku Usaha III \\
\hline $\begin{array}{l}\text { Kampung Suka Jawa Kecamatan } \\
\text { Bumiratu Nuban Kabupaten Lampung } \\
\text { Tengah }\end{array}$ & Pembimbingan ada & $\mathrm{Ya}$ & Ya \\
\hline $\begin{array}{l}\text { Desa Karang Rejo Kecamatan Negeri } \\
\text { Katon Kabupaten Pesawaran }\end{array}$ & $\begin{array}{l}\text { Sebatas pelatihan saja } \\
\text { perhatian pemerintah }\end{array}$ & Tidak tau & $\begin{array}{l}\text { Dalam pelatihan saja } \\
\text { bimbingannya }\end{array}$ \\
\hline
\end{tabular}

Tabel 19. Penyediaan Prasarana dari Pemerintah.

\begin{tabular}{|c|c|c|c|}
\hline \multirow{2}{*}{ Desa/Kecamatan/Kabupaten } & \multicolumn{3}{|c|}{ Informan } \\
\hline & Pelaku Usaha 1 & Pelaku Usaha II & Pelaku Usaha III \\
\hline $\begin{array}{l}\text { Kampung Suka Jawa Kecamatan } \\
\text { Bumiratu Nuban Kabupaten Lampung } \\
\text { Tengah }\end{array}$ & Ada bantuan alat & Tidak ada & $\begin{array}{l}\text { Ada, alat perajang dari } \\
\text { Kementerian Pertanian } \\
\text { tapi hasilnya kurang } \\
\text { maksimal kalau } \\
\text { dibandingkan sama yang } \\
\text { manual }\end{array}$ \\
\hline $\begin{array}{l}\text { Desa Karang Rejo Kecamatan Negeri } \\
\text { Katon Kabupaten Pesawaran }\end{array}$ & $\begin{array}{l}\text { Belum ada pembuatan } \\
\text { lanting } \\
\text { manual }\end{array}$ & $\begin{array}{l}\text { Tidak, semuanya saya rintis } \\
\text { dari awal tidak ada } \\
\text { keterlibatan pemerintah }\end{array}$ & $\begin{array}{l}\text { Masih diajukan, bantuan } \\
\text { peralatan seperti alat } \\
\text { pemotong }\end{array}$ \\
\hline $\begin{array}{l}\text { Desa Sindoasri Kecamatan Candipuro } \\
\text { Kabupaten Lampung Selatan }\end{array}$ & $\begin{array}{l}\text { Ada alat siller kembung, } 2 \\
\text { unit vacum dari } \\
\text { kementerian pertanian }\end{array}$ & Ya ada & $\begin{array}{l}\text { Tidak ada semuanya } \\
\text { modal sendiri, barang } \\
\text { pengaduk aja saya beli } \\
\text { sendiri bekas dari bos } \\
\text { dulu sebesar Rp } 10 \text { juta }\end{array}$ \\
\hline
\end{tabular}

Tabel 20. Penyediaan Dana Dari Pemerintah.

\begin{tabular}{|c|c|c|c|}
\hline \multirow[t]{2}{*}{ Desa/Kecamatan/Kabupaten } & \multicolumn{3}{|c|}{ Informan } \\
\hline & Pelaku Usaha 1 & Pelaku Usaha II & Pelaku Usaha III \\
\hline $\begin{array}{l}\text { Kampung Suka Jawa Kecamatan } \\
\text { Bumiratu Nuban Kabupaten Lampung } \\
\text { Tengah }\end{array}$ & $\begin{array}{l}\text { Belum ada masih sebatas } \\
\text { pelatihan }\end{array}$ & Tidak ada & Ada \\
\hline $\begin{array}{l}\text { Desa Karang Rejo Kecamatan Negeri } \\
\text { Katon Kabupaten Pesawaran }\end{array}$ & Belum ada bantuan dana & Tidak ada & $\begin{array}{l}\text { Bantuan modal dari } \\
\text { Jamsostek sekitar Rp } 40 \\
\text { juta }\end{array}$ \\
\hline
\end{tabular}

Sumber Data : Data Primer, 2012

secara mandiri menjadi instruktur untuk usahanya tanpa melibatkan pemerintah dalam operasionalnya.

Dukungan pemerintah tidak hanya dalam pelatihan namun juga penyediaan sarana dari pemerintah yang dapat menunjang pelaku usaha dalam menjalankan profesinya. Lebih detilnya dapat dilihat pada tabel 19. Selaras pada tabel diatas, penyaluran bantuan sarana prasarana untuk di lokasi sampel masih belum maksimal. Pelaku usaha memodali sendiri peralatannya meski membayar dengan harga yang sangat mahal. Dan peralatan yang ada benar-benar sangat membantu pekerjaan para pelaku usaha.

Selain dukungan sarana dan prasarana, dalam penelitian ini juga akan mengungkapkan penyediaan dana yang dilakukan oleh Pemerintah. Untuk melihat apakah pemerintah juga menyediakan dana buat para pelaku usaha, selengkapnya tertera pada tabel 20.

Dari tabel 21 di atas dapat dicermati bahwa, Pemerintah tidak sampai pada pemberian modal bagi para pelaku usaha, Pemerintahan hanya sebagai fasilitator bagi pelaku usaha dalam bentuk pelatihan.

Pemasaran yang dilakukan oleh para pelaku usaha tidak hanya di sekitar wilayah Lampung tetapi sudah merambah luar kota Lampung. Guna melihat perkembangan pemasaran yang dilakukan para pengusaha dengan menjalin koneksi oleh pihak swasta dapat dilihat pada tabel 22 . 
Tabel 22. Kerjasama dengan Swasta dalam Pemasaran.

\begin{tabular}{|c|c|c|c|}
\hline \multirow[t]{2}{*}{ Desa/Kecamatan/Kabupaten } & \multicolumn{3}{|c|}{ Informan } \\
\hline & Pelaku Usaha 1 & Pelaku Usaha II & Pelaku Usaha III \\
\hline $\begin{array}{l}\text { Desa Karang Rejo Kecamatan Negeri } \\
\text { Katon Kabupaten Pesawaran }\end{array}$ & Belum ada & $\begin{array}{l}\text { Ya, kemitraan di PT } \\
\text { Wahyunimandina, PT } \\
\text { Agunan Wijaya Sakti, PT. } \\
\text { Citra Pertiwi Brata Sena } \\
\text { yang bergerak di bidang } \\
\text { pertambangan }\end{array}$ & $\begin{array}{l}\text { Belum ada, masih } \\
\text { disekitar lampung dan } \\
\text { sistem sewa }\end{array}$ \\
\hline $\begin{array}{l}\text { Desa Sindoasri Kecamatan Candipuro } \\
\text { Kabupaten Lampung Selatan }\end{array}$ & Gak ada & $\begin{array}{l}\text { Ada dengan Panjang batu } \\
\text { semen untuk pemasaran } \\
\text { dan cikampek dan merak } \\
\text { itu pun baru rencana }\end{array}$ & $\begin{array}{l}\text { Di malang dengan } \mathrm{CV} \\
\text { Sokresh untuk } \\
\text { mengemas }\end{array}$ \\
\hline
\end{tabular}

Tabel 23. Bantuan Cara Mengelola Usaha.

\begin{tabular}{|c|c|c|c|}
\hline \multirow{2}{*}{ Desa/Kecamatan/Kabupaten } & \multicolumn{3}{|c|}{ Informan } \\
\hline & Pelaku Usaha 1 & Pelaku Usaha II & Pelaku Usaha III \\
\hline $\begin{array}{l}\text { Kampung Suka Jawa Kecamatan Bumiratu } \\
\text { Nuban Kabupaten Lampung Tengah }\end{array}$ & $\begin{array}{l}\text { Bantuan mengelola usaha } \\
\text { dari pelatihan }\end{array}$ & Ya, dari pelatihan itu & $\begin{array}{l}\text { Ya pelatihan manajemen } \\
\text { usaha }\end{array}$ \\
\hline $\begin{array}{l}\text { Desa Karang Rejo Kecamatan Negeri } \\
\text { Katon Kabupaten Pesawaran }\end{array}$ & Tidak & Tidak & $\begin{array}{l}\text { Ya, pelatihannya ada } \\
\text { yang dilakukan oleh } \\
\text { Jamsostek }\end{array}$ \\
\hline $\begin{array}{l}\text { Desa Sindoasri Kecamatan Candipuro } \\
\text { Kabupaten Lampung Selatan }\end{array}$ & Ya, pelatihan & Belum ada & $\begin{array}{l}\text { Tidak ada semuanya } \\
\text { hanya belajar dari } \\
\text { pengalaman }\end{array}$ \\
\hline
\end{tabular}

Sumber Data : Data Primer, 2012.

Tabel 24. Pemasaran Usaha

\begin{tabular}{|c|c|c|c|}
\hline \multirow{2}{*}{ Desa/Kecamatan/Kab. } & \multicolumn{3}{|c|}{ Informan } \\
\hline & Pelaku Usaha 1 & Pelaku Usaha II & Pelaku Usaha III \\
\hline $\begin{array}{l}\text { Kampung Suka Jawa Kecamatan Bumiratu } \\
\text { Nuban Kabupaten Lampung Tengah }\end{array}$ & $\begin{array}{l}\text { Melalui pameran } \\
\text { bantuan supaya usaha } \\
\text { herbal ini dapat dikenal }\end{array}$ & $\begin{array}{l}\text { Tidak, usaha kami sendiri } \\
\text { lakukan dengan } \\
\text { menitipkan barang } \\
\text { dagangan }\end{array}$ & $\begin{array}{l}\text { Tidak, saya titipkan di } \\
\text { warung-warung dan } \\
\text { masih seputar Lampung } \\
\text { Tengah }\end{array}$ \\
\hline $\begin{array}{l}\text { Desa Karang Rejo Kecamatan Negeri } \\
\text { Katon Kabupaten Pesawaran }\end{array}$ & $\begin{array}{l}\text { Tidak ada bantuan untuk } \\
\text { pemasaran, Cuma dari } \\
\text { omongan warga aja } \\
\text { sehingga usaha kami } \\
\text { bisa dikenal }\end{array}$ & $\begin{array}{l}\text { Tidak, hasil dari kerja } \\
\text { keras saya sendiri saya } \\
\text { tawarkan dan saya bawa } \\
\text { sampel dengan } \\
\text { menawarkan kepada } \\
\text { perusahaan dan persentasi } \\
\text { di hadapan mereka }\end{array}$ & $\begin{array}{l}\text { Tidak ada bantuan, } \\
\text { meski keinginan ada } \\
\text { untuk membuka ruko di } \\
\text { depan rumah }\end{array}$ \\
\hline $\begin{array}{l}\text { Desa Sindoasri Kecamatan Candipuro } \\
\text { Kabupaten Lampung Selatan }\end{array}$ & $\begin{array}{l}\text { Tidak, semuanya dari } \\
\text { usaha saya sendiri yang } \\
\text { menawarkan dagangan } \\
\text { sana sini }\end{array}$ & $\begin{array}{l}\text { Tidak ada semuanya saya } \\
\text { sendiri yang berusaha }\end{array}$ & $\begin{array}{l}\text { Tidak, untuk } \\
\text { pemasarannya dari } \\
\text { pelabuhan Merak dan } \\
\text { dipromosikan oleh teman }\end{array}$ \\
\hline
\end{tabular}

Sebagaimana tabel di atas, hanya sebagian saja yang melakukan kerjasama dengan pihak swasta. Selebihnya informan bekerja sendiri atau mencari koneksi dengan pihak swasta yang dapat memajukan usahanya.

Pengelolaan usaha yang dilakukan oleh para pelaku usaha, kemungkinan bisa diperoleh bantuan dari pihak lain agar dapat mengelola usahanya lebih profesional. Lebih lengkapnya dapat dilihat pada penuturan informan yang tersirat dalam tabel 23 .
Bantuan cara mengelola usaha menurut informan hanya diperoleh melalui pelatihanpelatihan, untuk perkembangan usaha selanjutnya diserahkan sepenuhnya kepada informan sehingga keberhasilan usahanya tertumpu pada kerja keras pelaku usaha tersebut.

Pemasaran merupakan bagian akhir dari proses produksi, memperbanyak jejaring dan menjangkau sektor luar menjadikan pemasaran yang tercapai lebih maksimal dan menjadikan hasil produksi banyak diminati. Selengkapnya prospek 
Tabel 25. Pemanfaatan Teknologi Dalam Usaha.

\begin{tabular}{|c|c|c|c|}
\hline \multirow{2}{*}{ Desa/Kecamatan/Kab } & \multicolumn{3}{|c|}{ Informan } \\
\hline & Pelaku Usaha 1 & Pelaku Usaha II & Pelaku Usaha III \\
\hline $\begin{array}{l}\text { Kampung Suka Jawa Kecamatan } \\
\text { Bumiratu Nuban Kabupaten Lampung } \\
\text { Tengah }\end{array}$ & $\begin{array}{l}\text { Ya, seperti mesin } \\
\text { perajang, oven }\end{array}$ & $\begin{array}{l}\text { Masih manual aja dengan } \\
\text { menggunakan lem } \\
\text { batangan, dulu sih pernah } \\
\text { punya tapi sekarang } \\
\text { sudah rusak }\end{array}$ & Masih manual \\
\hline $\begin{array}{l}\text { Desa Karang Rejo Kecamatan Negeri } \\
\text { Katon Kabupaten Pesawaran }\end{array}$ & $\begin{array}{lr}\text { Tidak ada } & \text { masih } \\
\text { tradisional } & \text { seperti } \\
\text { mesin parut } & \text { singkong, } \\
\text { pengepres } & \text { singkong } \\
\text { pun } & \text { masih } \\
\text { menggunakan tangan }\end{array}$ & $\begin{array}{l}\text { Kami miliki sendiri tanpa } \\
\text { ada campur tangan } \\
\text { pemerintah }\end{array}$ & $\begin{array}{l}\text { Masih modal sendiri } \\
\text { baru rencana dari } \\
\text { Jamsostek }\end{array}$ \\
\hline $\begin{array}{l}\text { Desa Sindoasri Kecamatan Candipuro } \\
\text { Kabupaten Lampung Selatan }\end{array}$ & $\begin{array}{l}\text { Ya alat vacuum sangat } \\
\text { berteknologi }\end{array}$ & $\begin{array}{l}\text { Ya, bantuan alat dari } \\
\text { departemen pertanian }\end{array}$ & $\begin{array}{l}\text { Semuanya saya beli } \\
\text { dengan uang sendiri }\end{array}$ \\
\hline
\end{tabular}

Sumber Data : Data Primer, 2012.

Tabel 26 . Dukungan Lembaga Permodalan.

\begin{tabular}{|c|c|c|c|}
\hline \multirow{2}{*}{ Desa/Kecamatan/Kab } & \multicolumn{3}{|c|}{ Informan } \\
\hline & Pelaku Usaha 1 & Pelaku Usaha II & Pelaku Usaha III \\
\hline $\begin{array}{l}\text { Kampung Suka Jawa } \\
\text { Kecamatan Bumiratu } \\
\text { Nuban Kabupaten } \\
\text { Lampung Tengah }\end{array}$ & $\begin{array}{l}\text { Sudah ada seperti BUMK ( } \\
\text { Badan Usaha Milik Kampung) }\end{array}$ & $\begin{array}{l}\text { BUMK sudah ada baru } \\
\text { dibentuk } 1 \text { bulan }\end{array}$ & $\begin{array}{l}\text { Dari Badan Usaha Milik } \\
\text { Kampung ( BUMK) sebesar } \\
\text { Rp } 1.500 .000\end{array}$ \\
\hline $\begin{array}{l}\text { Desa Karang Rejo } \\
\text { Kecamatan Negeri Katon } \\
\text { Kabupaten Pesawaran }\end{array}$ & $\begin{array}{l}\text { Belum ada sepertinya saya juga } \\
\text { kurang tahu }\end{array}$ & $\begin{array}{l}\text { Lembaga Permodalan kami } \\
\text { belum pernah meminjam }\end{array}$ & $\begin{array}{l}\text { Koperasi perindustrian } \\
\text { sekitar Rp } 10 \text { juta dengan } \\
\text { ketentuan setiap bulan } \\
\text { membyar Rp } 250.000 \text { untuk } \\
40 \text { x bayar }\end{array}$ \\
\hline $\begin{array}{l}\text { Desa Sindoasri Kecamatan } \\
\text { Candipuro Kabupaten } \\
\text { Lampung Selatan }\end{array}$ & $\begin{array}{l}\text { Saya pinjam modal hanya dari } \\
\text { BRI dengan jumlah pinjaman } \\
\text { sebesar Rp } 25.000 .000 / \text { bulan }\end{array}$ & $\begin{array}{l}\text { Modal kami dapat dari } \\
\text { Danamon pinjamannya } \\
\text { dengan agunan }\end{array}$ & $\begin{array}{l}\text { Pinjaman dari keluarga saja } \\
\text { karena saya takut untuk } \\
\text { pinjam keluar }\end{array}$ \\
\hline
\end{tabular}

Sumber Data : Data Primer, 2012.

pemasaran pada masing-masing sampel dapat disajikan pada tabel 24.

Dalam hal pemasaran, para pelaku usaha mengirimkan barang produksinya kepada para penjual tanpa adanya keterlibatan dari pemerintah. Dan bila ada kerjasama dengan pihak swasta itupun murni atas usahanya sendiri yang tekun memasarkan usahanya.

Dukungan teknologi dalam mendukung setiap kegiatan akan melahirkan dan menciptakan efektivitas dan efisiensi usaha dapat tercapai. Tidak memakan waktu lama merupakan alasan positif penggunaan teknologi dalam usaha. Sehingga jumlah produksi akan lebih mudah diperoleh dalam waktu yang singkat. Selengkapnya dapat dilihat pada tabel 25 .

Sebagian besar informan menggunakan alat teknologi yang dapat mendukung hasil usahanya, sedangkan yang masih manual dikarenakan mereka tidak memiliki kemampuan untuk membeli alat teknologi yang dapat mendukung usahanya.
Modal menjadi suatu permasalahan dalam produksi apabila tidak terpenuhi dengan baik, guna mengatasi hal tersebut para pelaku usaha menutupi kekurangan modalnya dengan meminjam salah satu koperasi atau lembaga permodalan lainnya yang ada didesa, untuk lengkapnya dapat dilihat pada tabel di bawah ini :

Mencermati fakta di lapangan pada tabel di atas, mengungkapkan bahwa lembaga permodalan yang membantu informan adalah BUMK, Koperasi dan dari perbankan. Lembaga permodalan tersebut memberikan bantuan dengan bunga ringan dan pinjamannya disertai agunan.

Pameran hasil usaha menjadi sebuah ekspos hasil-hasil produksi yang dilakukan oleh para pelaku usaha. Selain itu pameran juga dapat sebagai ajang promosi bagi pelaku usaha yang ingin lebih memperkenalkan produknya kepada publik. Untuk melihat pameran yang dilaksanakan oleh pemerintah, dapat dilihat pada tabel berikut ini : 
Tabel 27. Pameran yang Dilakukan oleh Pemerintah.

\begin{tabular}{|c|c|c|c|}
\hline \multirow{2}{*}{ Desa/Kecamatan/Kab } & \multicolumn{3}{|c|}{ Informan } \\
\hline & Pelaku Usaha 1 & Pelaku Usaha II & Pelaku Usaha III \\
\hline $\begin{array}{l}\text { Kampung Suka Jawa } \\
\text { Kecamatan Bumiratu } \\
\text { Nuban Kabupaten } \\
\text { Lampung Tengah }\end{array}$ & $\begin{array}{l}\text { Ya, pameran selalu ada setiap } \\
\text { tahun }\end{array}$ & Ya, di kabupaten & $\begin{array}{l}\text { Ya, pameran lokal dan nasional } \\
\text { di Bandung dan dibbiayai oleh } \\
\text { Bupati Lampung Tengah }\end{array}$ \\
\hline $\begin{array}{l}\text { Desa Karang Rejo } \\
\text { Kecamatan Negeri Katon } \\
\text { Kabupaten Pesawaran }\end{array}$ & $\begin{array}{l}\text { Pameran iya ada di Kabupaten, } \\
\text { dan itu salah satu saya bisa } \\
\text { promosi lanting ini }\end{array}$ & $\begin{array}{l}\text { Selama ini saya belum pernah } \\
\text { ikut terlibat dalam pameran }\end{array}$ & $\mathrm{Ya}$ \\
\hline $\begin{array}{l}\text { Desa Sindoasri Kecamatan } \\
\text { Candipuro Kabupaten } \\
\text { Lampung Selatan }\end{array}$ & Pernah dari dinas pertanian & $\begin{array}{l}\text { Iya, } \quad \text { kadang } \\
\text { Kabupaten/kecamatan }\end{array}$ & Belum pernah \\
\hline
\end{tabular}

Sumber Data : Data Primer, 2012

Tabel 28. Faktor Pendukung dan Penghambat.

\begin{tabular}{|c|c|c|c|}
\hline \multirow{2}{*}{ Desa/Kecamatan/ Kab } & \multicolumn{3}{|c|}{ Informan } \\
\hline & Pelaku Usaha 1 & Pelaku Usaha II & Pelaku Usaha III \\
\hline $\begin{array}{l}\text { Kampung Suka Jawa } \\
\text { Kecamatan Bumiratu Nuban } \\
\text { Kabupaten Lampung Tengah }\end{array}$ & $\begin{array}{l}\text { Faktor pendukungnya adalah } \\
\text { dari BKKBN berupa alat-alat } \\
\text { yang terbuat dari stainless, } \\
\text { kendalanya terletak pada iklim } \\
\text { dan musim penghujan yang } \\
\text { bisa mematikan pembibitan }\end{array}$ & $\begin{array}{l}\text { Persaingan banyak, } \\
\text { barang susah didapat dan } \\
\text { harus ke tanjung karang. } \\
\text { Pendukungnya banyak }\end{array}$ & $\begin{array}{l}\text { Faktor pendukungnya bahan } \\
\text { baku mudah didapat, kendalanya } \\
\text { packingnya kurang dan maunya } \\
\text { yang berbentuk kardus serta } \\
\text { saingannya banyak }\end{array}$ \\
\hline $\begin{array}{l}\text { Desa Karang Rejo Kecamatan } \\
\text { Negeri Katon Kabupaten } \\
\text { Pesawaran }\end{array}$ & $\begin{array}{l}\text { Faktor penghambatnya yaitu } \\
\text { kesulitan pada permodalan } \\
\text { untuk beli bantuan alat karena } \\
\text { kami kesulitan untuk } \\
\text { memencetnya jika datang hari } \\
\text { hujan. Pendukungnya adalah } \\
\text { persaingan banyak tapi kami } \\
\text { bersaing sehat jadinya tidak ada } \\
\text { masyarakat disini yang } \\
\text { memiliki sifat iri terhadap } \\
\text { usaha kami }\end{array}$ & $\begin{array}{l}\text { Penghambatnya yaitu bila } \\
\text { musim kemarau akan } \\
\text { mengurangi jumlah } \\
\text { pemesanan, dan bila } \\
\text { masuk penghujan } \\
\text { permintaan semakin } \\
\text { banyak. Pendukungnya } \\
\text { kompetitor untuk usaha } \\
\text { ini cenderung sedikit dan } \\
\text { itu modal untuk bisa saya } \\
\text { buka cabang untuk usaha } \\
\text { ini }\end{array}$ & $\begin{array}{l}\text { Faktor pendukungnya tenaga } \\
\text { kerja tidak ada yang bermasalah, } \\
\text { faktor hambatannya bahan baku } \\
\text { sulit dan kadang bagus atau } \\
\text { tidak, pemasaran yang juga jadi } \\
\text { kendala dan modal }\end{array}$ \\
\hline $\begin{array}{l}\text { Desa Sindoasri Kecamatan } \\
\text { Candipuro Kabupaten } \\
\text { Lampung Selatan }\end{array}$ & $\begin{array}{l}\text { Dukungannya, pak camat } \\
\text { sangat mendukung usaha kami } \\
\text { Penghambatnya bahan baku } \\
\text { sulit untuk pembuatan kripik } \\
\text { pisang,tdak sebanding dengan } \\
\text { permintaan pasar yang semakin } \\
\text { tinggi. }\end{array}$ & $\begin{array}{l}\text { Kendalanya bahan baku } \\
\text { pisang yang sulit dan } \\
\text { persaingannya ketat, } \\
\text { dukunganya konsumen } \\
\text { tetap mencari produk } \\
\text { kami meski banyak } \\
\text { pedagang mengeluarkan } \\
\text { kripik pisang dengan citra } \\
\text { rasa yang berbeda. }\end{array}$ & $\begin{array}{l}\text { Penghambat hanya modal saja, } \\
\text { pendukungnya bahan baku } \\
\text { mudah didapat }\end{array}$ \\
\hline
\end{tabular}

Sumber Data : Data Primer, 2012.

Mayoritas informan pelaku usaha mengungkapkan bahwa mereka secara aktif mengikuti pameran yang berlangsung. Dan dari keikutsertaannya dalam pameran, hasil produknya dapat diketahui masyarakat umum.

Faktor pendukung dan penghambat yang dihadapi pelaku usaha dalam mengembangkan profesinya dapat dilihat pada tabel 28 .

Sebagaimana yang tertuang dalam tabel di atas, menyiratkan bahwa informan menghadapi kendala pada ketersediaan bahan baku, pemasaran, tingkat persaingan yang tinggi dan faktor pendukungnya adalah tertuju pada dukungan dari pemerintah terkait maupun tenaga kerja yang cukup dihandalkan.
Kewirausahaan desa selain untuk memperbaiki penghasilan masyarakat juga dapat menjadi sarana pembelajaran bagi masyarakat untuk memiliki daya saing dan unggul dalam memanfaatkan potensi-potensi yang ada didesanya atau juga menjadi intrument bagi masyarakat untuk menggali bakat dan kemampuannya. Untuk melihat strategi yang dilakukan oleh para pengambil kebijakan di tingkat daerah dan desa dapat diinventarisir pada tabel 29.

Seperti kita ketahui menggali potensi dalam diri sendiri tidaklah mudah, berbagai cara dilakukan oleh para pelaku usaha untuk mencoba berbagai peluang usaha yang ada di desa. Sampai saat ini para pelaku usaha menikmati perannya sebagai pengusaha 
Tabel 29. Strategi Pemerintah Daerah dan Desa dalam Mengembangkan Kewirausahaan.

\begin{tabular}{|c|c|c|}
\hline \multirow{2}{*}{ Desa/Kecamatan/Kab } & \multicolumn{2}{|c|}{ Informan } \\
\hline & Pemerintah Daerah & Pemerintah Desa \\
\hline $\begin{array}{l}\text { Kampung Suka Jawa Kecamatan } \\
\text { Bumiratu Nuban Kabupaten } \\
\text { Lampung Tengah }\end{array}$ & $\begin{array}{l}\text { Strateginya secara intensif melatih } \\
\text { mereka bahkan membuka jejaring } \\
\text { dengan pihak lain seperti yang ingin } \\
\text { menjalin kemitraan dengan Unila }\end{array}$ & $\begin{array}{l}\text { Strateginya adalah dengan (1) berupaya } \\
\text { untuk pembibitan ikan karena potensi } \\
\text { disni banyak kolam ( } 2 \text { ) ada limbah } \\
\text { pakan ikan dari ternak seudah berjalan } \\
\text { dan dibentuk ikan patin. (3) membentuk } \\
\text { kelompok pengguna limbah pakan ikan } \\
\text { dan mereka yang sudah punya ikan dan } \\
\text { saat ini sudah berjalan selama } 2 \text { tahun, } \\
\text { (4) dan memprosesnya untuk menjadi } \\
\text { makanan ikan dan bila ada keterkaitan } \\
\text { dengan mereka dan pelatihannya di } \\
\text { Sukabumi }\end{array}$ \\
\hline $\begin{array}{l}\text { Desa Karang Rejo Kecamatan } \\
\text { Negeri Katon Kabupaten } \\
\text { Pesawaran }\end{array}$ & $\begin{array}{l}\text { Strateginya dengan mengirim pelaku } \\
\text { usaha yang ada di desa biar mereka bisa } \\
\text { sekaligus mempromosikan usahanya }\end{array}$ & $\begin{array}{l}\text { Harus terus dibekali dan didampingi } \\
\text { tidak dilepaskan begitu saja para } \\
\text { pengusaha ini, karena bagaimanapun } \\
\text { mereka para pelaku secara langsung } \\
\text { membuka lapangan kerja buat } \\
\text { masyarakat sekitar dan juga kami ingin } \\
\text { membentuk koperasi biar bisa diadakan } \\
\text { untuk menampung hasil-hasil usaha } \\
\text { masyarakat }\end{array}$ \\
\hline $\begin{array}{l}\text { Desa Sindoasri Kecamatan } \\
\text { Candipuro Kabupaten Lampung } \\
\text { Selatan }\end{array}$ & $\begin{array}{l}\text { Strateginya kami ingin mengembangkan } \\
\text { produk unggulan di sini yaitu sawit, } \\
\text { dengan alasan (1) lokasi sawit sangat } \\
\text { besar, (2) dan sampai saat ini kami ingin } \\
\text { bekerjasama dengan unila untuk } \\
\text { menjadi home industri dan juga ingin } \\
\text { membuat suatu desa percontohan yaitu } \\
\text { desa batulima yang mana dari daun } \\
\text { sawit akan diintegrasikan untuk pupuk } \\
\text { organik yang dicampur dengan batang } \\
\text { padi untuk menjadi pakan ternak. }\end{array}$ & $\begin{array}{l}\text { Dengan bantuan sarana prasarana, } \\
\text { pelatihan } 3 \text { hari dan pelatihan } 3 \text { hari } \\
\text { tersebut diambil dari tetangga-tetangga } \\
\text { dan dusun sekitar } 25 \text { orang dan bantuan } \\
\text { dari pertanian yaitu CSR. }\end{array}$ \\
\hline
\end{tabular}

Sumber Data : Data Primer, 2012.

dengan melakukan inovasi, kreativitas dan imajinasinya dalam mengembangkan produksi usahanya baik dalam hal pengemasan, citra rasa, kualitas, pemasaran maupun manajemen. Seperti yang dilakukan dalam usaha kripik pisang yang awalnya memiliki rasa coklat, dan gurih tetapi sekarang sudah berkembang menjadi rasa melon, strawbery, mocca, keju, susu, balado, coco coffe, durian, melon bahkan produksi dikembangkan lagi ke produk pembuatan kripik buah yang berasa nangka, nanas. Pengaromaan usaha kripik buah tersebut diperoleh dari hasil pemagangan di Malang. Hal ini sepadan dengan yang dikemukakan oleh Prawirokusumo yaitu Wirausaha adalah mereka yang melakukan upaya-upaya kreatif dan inovatif dengan jalan mengembangkan ide, dan meramu sumberdaya untuk menemukan peluang (opportunity) dan perbaikan (preparation) hidup. Diperkuat juga oleh Zimmerer bahwa untuk mencapai pengembangan kewirausahaan melalui cara-cara sebagai berikut: (1) Pengembangan teknologi baru (developing new technology) yang dapat diamati dari pengaplikasian alat-alat pendukung usaha para pelaku yang terdiri dari vacum, alat pemotong, dll. (2) Penemuan pengetahuan baru (discovering new knowledge), hal ini bisa diperoleh melalui pemagangan. Dimana informan ada yang melakukan tukar pengetahuan di daerah Malang untuk mengetahui pengemasan yang dilakukan oleh CV.Sokresh maupun Pemagangan di Bejo Keramik dan (3) Perbaikan produk (barang dan jasa) yang sudah ada (improving existing products or services), dan (4) Penemuan cara-cara yang berbeda untuk menghasilkan barang dan jasa yang lebih banyak dengan sumber daya yang lebih sedikit (finding different ways of providing more goods and services with fewer resources).

Penggalian gagasan ide untuk mengembangkan usaha para pelaku, dirasakan dapat disinkronkan dengan potensi desa yang ada. Hal ini sebagai salah satu menjaga kearifan lokal dan pemanfaatan SDA yang ada. Menurut Muhi (2011) potensi desa mencakup: (1) potensi geografis desa (aspek topologi dan aspek non biotik); (2) potensi sumberdaya alam di wilayah desa (sumberdaya tanah, sumberdaya hutan, serta sumberdaya air dan kelautan); (3) potensi sumberdaya manusia di perdesaan (angkatan kerja dan pengangguran); (4) sumberdaya ekonomi di perdesaan (potensi ekonomi desa, peluang kerja, dan usaha di desa); (5) potensi sosial dan budaya di perdesaan; (6) potensi kelembagaan di desa; (7) sarana dan prasarana di desa. Bervariasinya usaha yang digeluti para pelaku 
menjadikan adanya tuntutan untuk melakukan intriks-intriks yang bisa tampil beda, sehingga konsumen tidak berpaling pada produk lainnya. Misalnya dalam hal jenis usaha yang langka dan jarang dilakukan oleh pengusaha lain seperti produksi pupuk organik. Selain membutuhkan modal yang sangat besar namun usaha ini juga menuntut pengusaha memiliki jaringan koneksi yang kuat. Selaras pula yang dikemukakan oleh Druckjer bahwa Kewirausahaan adalah kemampuan untuk menciptakan sesuatu yang baru dan berbeda.

Pengembangan kewirausahaan dilaksanakan sesuai dengan minat, bakat, potensi kaum muda, potensi daerah, dan arah pembangunan nasional. Dalam kaitan ini, pemerintah, pemerintah daerah, organisasi kepemudaan dan/atau masyarakat melakukan penelusuran dan identifikasi terhadap minat, bakat, serta potensi kaum muda. Pemerintah melakukan pemetaan potensi nasional dalam rangka pengembangan kewirausahaan. Pemerintah daerah melakukan pemetaan potensi daerah dalam rangka pengembangan kewirausahaan. Adapun Fasilitasi pengembangan kewirausahaan dilaksanakan melalui: (1) pelatihan; (2) pemagangan; (3) pembimbingan; (4) pendampingan; (5) kemitraan; (6) promosi; dan (7) bantuan akses permodalan.

Pada dasarnya pemberdayaan ekonomi masyarakat adalah penguatan pemilikan faktor-faktor produksi, penguatan penguasaan distribusi dan pemasaran, penguatan masyarakat untuk mendapatkan gaji/upah yang memadai, dan penguatan masyarakat untuk memperoleh informasi, pengetahuan dan ketrampilan, yang harus dilakukan secara multi aspek, baik dari aspek masyarakatnya sendiri, maupun dari aspek kebijakannya. Karena pada umumnya program Pemberdayaan bertujuan untuk mengembangkan kreativitas di bidang usaha masyarakat, membangun pertumbuhan ekonomi masyarakat serta pemberdayaan kegiatan dan peningkatan pendapatan. Artinya bahwa pengelolaan usaha ekonomi masyarakat dibutuhkan orang yang memiliki jiwa inovatif, kreatif serta berani mengambil resiko namun tidak meninggal semangat persaudaraan yang tumbuh dan berkembang di tengah-tengah masyarakat setempat.

Para pelaku usaha praktiknya mengalami hambatan dalam permodalan, berupaya mencari modal yang bersumber dari perbankan, koperasi dan Badan Usaha Milik Kampung (BUMK). Hal yang perlu dicermati dalam usaha pemberdayaan masyarakat di bidang ekonomi melalui aspek permodalan ini adalah: (1) bagaimana pemberian bantuan modal ini tidak menimbulkan ketergantungan masyarakat; (2) bagaimana pemecahan aspek modal ini dilakukan melalui penciptaan sistem yang kondusif baru usaha mikro, usaha kecil, dan usaha menengah untuk mendapatkan akses di lembaga keuangan; (3) bagaimana skema penggunaan atau kebijakan pengalokasian modal ini tidak terjebak pada perekonomian subsisten atau ekonomi kere. Tiga hal ini penting untuk dipecahkan bersama. Karena inti pemberdayaan adalah kemandirian masyarakat.

Tidak hanya permodalan, tetapi para pelaku usaha juga membutuhkan Pendampingan dan sampai saat ini belum dilakukan intesif pedampingan yang dilakukan pemerintah kepada pengusaha. Tugas utama pendamping ini adalah memfasilitasi proses belajar atau refleksi dan menjadi mediator untuk penguatan kemitraan baik antara usaha mikro, usaha kecil, maupun usaha menengah dengan usaha besar. Sedangkan pelatihan yang dilakukan oleh Pemerintah dalam menumbuhkembangkan potensi wirausaha di desa adalah dengan cara membekali mereka dengan pelatihan seperti pelatihan manajemen usaha, pelatihan tentang disain kemasan, manajemen pemasaran, pembukuan sederhana, dan motivasi usaha ekonomi keluarga, pelatihan mengenal zat pewarna, pelatihan sertifikasi SIUP, dll seperti yang telah tersirat pada tabel di atas. Dan Pelatihan tersebut hanya diikuti oleh sebagian informan yang menjadi sampel dalam penelitian ini, khusus untuk Pengusaha Kemplang sampai saat ini belum pernah mengikuti pameran ataupun pelatihan yang diselenggarakan oleh pemerintah.

Di tambah lagi pemerintah desa sendiri pun belum sepenuhnya mampu mengembangkan wirausaha yang ada di desa, karena pelaku usaha secara mandiri membangun usahanya melalui kerja keras dan ketekunan. Lemahnya peran pemerintah desa dalam mensupport para pelaku usaha akan memungkinkan tidak tercapainya tujuan pengembangan kewirausahaan secara optimal. Seperti yang ditekankan pula oleh Anto bahwa tujuan pengembangan kewirausahaan desa hanya akan tercapai secara optimal apabila tokoh desa, dalam hal ini kepala desa, memiliki spirit atau semangat kewirausahaan desa yang tinggi. Sebagai kepala desa, dia adalah sosok yang musti "lengkap" semangatnya di dalam mengelola kondisi sosial masyarakat. Jika kepala desanya tidak memiliki semangat kewirausahaan, maka harus ada staf-nya yang pandir di dalam hal kewirausahaan. Kepala desa harus sering-sering mengumpulkan tokoh-tokoh kampng (RT/RW) dan di ajak berbincang tentang kewirausahaan

Berdasarkan penelitian yang dilakukan oleh penulis dapat diketahui temuan-temuan lapangan yang bisa menjadikan suatu bahan masukan yang signifikan kepada pemangku kebijakan yang ada yaitu; (1) Pemerintah daerah masih sebatas memfasilitasi pelaksanaan pelatihan dan tidak sampai pada tahap pedampingan maksimal di lapangan; (2) Pemerintah desa belum optimal dalam mengembangkan kewirausahaan di desa, perannya hanya sebatas mengusulkan peserta yang akan mengikuti pelatihan; (3) Mayoritas pelaku usaha masih menggunakan alat tradisional untuk menyelesaikan proses produksi; (4) Pengembangan 
kewirausahaan yang ada didesa masih pada kategorisasi usaha kecil dalam keluarga; (5) Sebagian masyarakat sampel, belum membuat produk hukum yang berkenaan dengan pengembangan kewirausahaan desa, (6) Pengembangan kewirausahaan desa berdasarkan potensi di desa masing-masing, hanya saja untuk memperoleh bahan baku untuk produksinya tersebut di peroleh di wilayah lain, (7) Minimnya pengaplikasian administrasi pembukuan yang dilakukan oleh para pelaku usaha dalam menjalankan usahanya, (8) Produk Pengemasan untuk jenis usaha makanan masih terbilang sederhana; (9) Pemasaran produksi masih sebatas regional yang sama, dan bilapun ada yang ke luar wilayah Lampung itu pun atas kemitraan yang dilakukan oleh pelaku usaha tanpa ada campur tangan dari pemerintah.

Sehubungan dengan hal tersebut, maka langkah tepat yang dapat dikembangkan untuk membangkitkan gairah kewirausahaan di desa dapat dilihat pada gambar berikut ini: pedampingan dan pengawasan langsung kepada para pelaku usaha sebagai wujud atensi dari pemangku kebijakan, (3) membuat regulasi berupa Pergub/Perbup atau Perda yang mengangkat masalah pengembangan kewirausahaan desa, (4) pemerintah dapat menjembatani antara pelaku usaha dengan perusahaan swasta. Sehingga terbuka peluang pelaku usaha di desa untuk bekoordinasi dan mempromosikan produknya, (5) menganggarkan pengembangan kewirausahaan pada tahun berikutnya agar tidak hanya pelatihan yang bisa diperoleh pelaku usaha namun juga permodalan, (6) para pelaku usaha dapat mengembangkan ide usahanya lebih maksimal melalui studi banding ke pelaku usaha lain yang sejenis, guna bertukar pikiran ataupun mempelajari hal-hal positif yang bermanfaat bagi usahanya misalnya dalam hal pemasaran, pengemasan, ataupun pembukuan, (7) pelaku usaha dapat membentuk kelompok usaha yang sejenis di dalam desa, agar menjadi semakin solid dan bisa membangun usahanya yang lebih besar dari yang

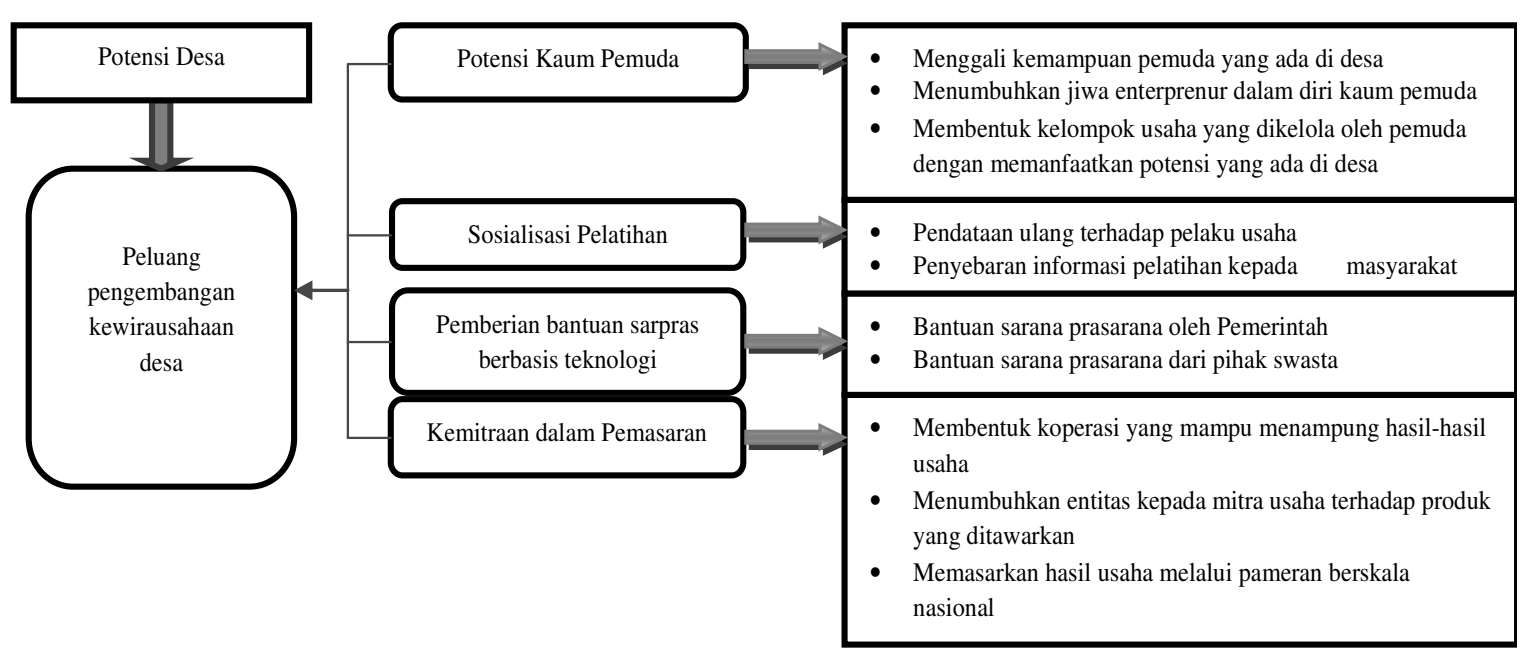

\section{SIMPULAN}

Sejalan dengan lajunya perkembangan kewirausahaan di desa, ada beberapa hal yang dapat disimpulkan yaitu Peluang pengembangan kewirausahaan desa sangat besar dan dikategorikan sebagai usaha kecil dengan produk unggulannya yaitu bidang pertanian, perkebunan dan adanya pemanfaatan sumber daya alam yang juga potensial. Kewirausahaan yang ada di desa memiliki prospek yang bagus asalkan didukung oleh sarana prasarana, regulasi yang pro ke pelaku usaha dan adanya kepercayaan dari pihak lain untuk menjaring kemitraan kepada pelaku usaha.

Dari apa yang tertera pada kesimpulan, saran yang dapat kami sampaikan guna mengembangkan kewirausahaan di desa adalah sebagai berikut : (1) pendataan ulang yang uptodate bagi para pelaku usaha dengan seksama dan valid serta membuat data base progress perkembangan usaha para pelaku secara terperinci dan komprehensif, (2) melakukan semula, (8) membuat administrasi pembukuan secara sederhana untuk mengetahui perkembangan usaha yang ditekuninya.

\section{DAFTAR PUSTAKA}

Anto, Sugianto. 2011. "Menggagas Kewirausahaan Desa." Kompasiana, 16 Juni 2011.

Cakera, I Ketut. 2012. "Bangun Wirausaha Idealnya Rp. 5 Miliar Per Tiap Tahun", Suara Pembaharuan, Selasa 3 April 2012.

Hasan,Syarifuddin. 2011. "Jumlah Wirausaha Indonesia Masih rendah", Kompas.com, Minggu 27 Pebruari 2011.

Irawady, EdyPutra. 2011. "Pemda Diimbau Kembangkan Potensi Wirausaha", Info Publik Ditjen Informasi dan Komunikasi Politik, Kamis, 12 Mei 2011.

Lestari, Dewi. 2011. Konsep Pengembangan Desa Entrepreneur. FE Tanjungpura 
Muhi, Ali Hanapiah. 2011. Desa: Analisis Permasalahan, Potensi, dan Pengembangan. Jatinangor: Alqa Prisma.

Mujahidin. 2012. Perilaku Negara Dalam mengembangkan Kewirausahaan. Sumut: IKS FISIP UMSU.

Ningsih, Suria. 2012. Urbanisasi dan Kaitannya Dengan Hukum dan Kependudukan. Sumut: FH USU.

Peraturan Pemerintah RI No. 41 Tahun 2011 Tentang Pengembangan Kewirausahaan dan Kepeloporan Pemuda, Serta Penyediaan Prasarana dan Prasarana Kepemudaan.

Pusat Kurikulum Balitbang Kemendiknas. 2010. Pengembangan Pendidikan Kewirausahaan. Jakarta: PKB Kemendiknas.

Radjasa, Hatta. 2012. "Indonesia Perlu 4 Juta Wirausaha", Tribun Kalteng, Minggu 29 April 2012.

Tjiptoherijanto, Prijono. 2007. Urbanisasi, Mobilitas, dan Perkembangan Perkotaan di Indonesia. Jakarta: FE-UI.

Undang-undang No. 40 Tahun 2009 Tentang Kepemudaan.

, Ada 3,744 Juta Wirausahawan Selama 2011. 2012. Tribunnews.com, Kamis 8 Maret 2012.

Jumlah Wirausahawan Perlu Ditingkatkan. 2011. Lampung Post.Com, Jum'at 25 Nopember 2011.

,Potensi Besar Wirausaha Desa Belum Tergarap. 2012. Pikiran Rakyat Online, Selasa 13 Juli 2012. 